\title{
Universiteit
}

Leiden

The Netherlands

\section{Effectiveness of Poverty Reduction in the EU15. A Descriptive Analysis} Caminada, C.L.J.; Goudswaard, K.P.

\section{Citation}

Caminada, C. L. J., \& Goudswaard, K. P. (2009). Effectiveness of Poverty Reduction in the EU15. A Descriptive Analysis. Poverty \& Public Policy, 1(2, Article 5), 1-51. Retrieved from https://hdl.handle.net/1887/15438

Version: $\quad$ Not Applicable (or Unknown)

License: $\quad$ Leiden University Non-exclusive license

Downloaded from: https://hdl.handle.net/1887/15438

Note: To cite this publication please use the final published version (if applicable). 


\section{Poverty \& Public Policy}

A Global Journal of Social Security, Income, Aid, and Welfare

www.psocommons.org/ppp/

Volume 1 , Issue $2 \cdot 2009 \cdot$ Article 5

\section{Effectiveness of Poverty Reduction in the EU: A Descriptive Analysis}

Koen Caminada, Leiden University, Leiden Law School, Department of Economics Kees Goudswaard, Leiden University, Leiden Law School, Department of Economics

Published on behalf of the Policy Studies Organization

Caminada, Koen and Goudswaard, Kees (2009) "Effectiveness of Poverty Reduction in the EU: A Descriptive Analysis," Poverty \& Public Policy: Vol. 1: Iss. 2, Article 5.

Available at: http:/www.psocommons.org/ppp/vol1/iss2/art5

DOI: $10.2202 / 1944-2858.1023$ 


\title{
Effectiveness of Poverty Reduction in the EU: A Descriptive Analysis
}

\author{
Koen Caminada, Leiden University, Leiden Law School, Department of \\ Economics \\ Kees Goudswaard, Leiden University, Leiden Law School, Department of \\ Economics
}

\begin{abstract}
The European Union coordinates and encourages Member State actions to combat poverty, and to reform their social protection systems on the basis of policy exchanges and mutual learning ('best practices'). This paper analyses the effectiveness of welfare state policies and especially social transfers in EU-countries in alleviating poverty. To indicate whether European economic integration may have had any impact on poverty reduction, we also include several non-EU15 countries as a benchmark into our analysis. We analyze on a cross-country basis the relationship between poverty rates and social effort, as measured by social expenditure ratios. We also correct these expenditure ratios for the impact of the tax system and for private social arrangements, using OECD methodology. Next, we compare poverty rates at the levels of market and disposable incomes; that is, before and after transfers, in order to analyze the effect of tax and transfer policies in reducing poverty, i.e., to determine the target efficiency of social transfers. We perform several tests with the most recent data.

Our results are less clear cut than earlier findings. We still find a quite strong negative relationship between the level of social expenditure and poverty among OECD countries. However, for EU-countries this relationship is weaker and there are substantial differences within the EU15. After correcting for the impact of taxes and for private social arrangements, the linkage between social effort and poverty levels becomes even weaker. Also, we do not find a strong relationship between levels of social spending and antipoverty effects of social transfers and taxes. At the program level, family programs and child support alleviate poverty to a large extent.
\end{abstract}

KEYWORDS: poverty, welfare states, Lisbon objectives, social indicators

\begin{abstract}
Author Notes:
Koen Caminada (Ph.D., Leiden University) studied economics at the Erasmus University Rotterdam, and at the Catholic University Leuven. He is professor of Empirical Analysis of Tax and Social Policy at Leiden University. His research interests include: empirical analysis of tax law and social policy, social security, fiscal and tax policy, and income distribution and poverty. Website with downloadable publications: http://www.law.leiden.edu/organisation/ taxlawandeconomics/economics/staff/caminada.html. Kees Goudswaard (Ph.D., Leiden University) studied Economics at the Free University of Amsterdam. He is Professor of Economics at the Faculty of Law, Leiden University, the Netherlands and Professor of Social Security at the Gak Foundation. Goudswaard is also chairman of the Committee of Social and
\end{abstract}


Economic Experts of the Social and Economic Council, which is the main government advisory body on economic policy in the Netherlands. His research areas are: welfare state economics and public finance. He has published many articles along with several books, covering issues with regard to budgetary policy, social policy, pensions and income distribution. Website with downloadable publications: http://www.law.leiden.edu/organisation/taxlawandeconomics/ economics/staff/goudswaard.html.

Revised version of a paper presented at the 66th International Atlantic Economic Conference, Montreal, Canada, October 11th 2008, and at the Nake Research Day, Utrecht, October 24th 2008. We thank John Beirne, Ross Gittell, Henk Nijboer, Ben van Velthoven, Cok Vrooman for useful comments on a earlier draft of this paper. This study is part of the research program 'Reforming Social Security': www.hsz.leidenuniv.nl. Financial support of Stichting Instituut GAK is gratefully acknowledged. 
Caminada and Goudswaard: Effectiveness of Poverty Reduction in the EU

\section{Introduction}

Poverty alleviation has been a European objective since the Treaty of Rome in 1957. In 2000 the European Council (EC) adopted the goal that besides economic growth, social cohesion also should be strengthened in the European Union (EU) as part of the Lisbon Agenda. The open method of coordination was introduced as the means of spreading best practices and achieving greater convergence towards the main EU-goals. Social indicators were developed to monitor the improvements with respect to social cohesion.

The Lisbon Agenda has renewed interest in poverty alleviation across member states. However, a sizable proportion of the EU15 population still lives in poverty (16 percent), although both poverty structure and poverty rates vary across countries (from 10 percent in the Netherlands to about 20 percent in Greece, Spain and Portugal). Moreover, the average at-risk-of-poverty rates - an official EU social cohesion indicator - have even risen since the adoption of the Lisbon Agenda.

Some EU-countries are more effective in poverty reduction than others. What can explain these variations in effectiveness? Obviously, a range of policy strategies may be chosen to tackle poverty, including improving educational outcomes, improving job opportunities and stimulating labor force participation and reducing inequalities in health outcomes. This paper analyses the effectiveness of income transfer policies in EU-countries in alleviating poverty. To indicate whether European economic integration may have had any impact on poverty reduction, we also include in our analysis several non-EU15 countries as a benchmark. We analyze on a cross-country basis the relationship between poverty rates and social effort, as measured by social expenditure ratios. We also correct these expenditure ratios for the impact of the tax system and for private social arrangements, using OECD methodology. ${ }^{1}$ Next, we compare poverty rates at the levels of market and disposable incomes, that is before and after taxes and social transfers, in order to analyze the effect of tax and transfer policies in reducing poverty, i.e. to determine the target efficiency of social transfers. We will perform several tests with data from the Luxembourg Income Study (LIS), the Organization for Economic Co-operation and Development (OECD), and Eurostat (ECHP/EU-SILC) and compare our results with earlier findings on crosscountry poverty research.

Finally, we will perform several partial analyses (using recent data from the European Commission,) in order to investigate to what extent variations at the social program level (such as old age pensions, child benefits) affect the measured effectiveness of the welfare state in alleviating poverty.

${ }^{1}$ Caminada and Goudswaard (2005). 


\section{Policy on poverty alleviation}

2.1 Europeanization of social policies. Member states of the EU remain autonomous when it comes to the design and generosity of their social protection systems. Still, member states have accepted a certain degree of commitment in terms of social protection. This commitment is embodied in two recommendations accepted by the European Council in 1992. ${ }^{2}$ The first recommendation, June 1992, dealt with common criteria concerning sufficient resources and social assistance in social protection systems. The second, July 1992, addressed the "convergence of social protection objectives and policies." The motivation was that convergence seeks to guarantee the continuation and stimulation of the development of social protection within the internal market.

A new and important step was taken at the European Council in Lisbon, in 2000. For the EU the strategic goal was set for the decade ending in 2010 to become the most competitive and dynamic knowledge-based economy with sustainable economic growth and greater social cohesion. The economic and social agendas were thus explicitly coupled. When trying to reconcile equity and efficiency objectives, however, trade-offs may appear. It is well known from economic theory that a reduction of inequality (greater social cohesion) by means of redistribution creates labor market distortions and thus less economic efficiency. On the other hand, more recent research suggests that there are also welfare gains from income redistribution including poverty amelioration. The argument is that more equality contributes to public support for a dynamic market economy, which makes it possible to reap efficiency gains from competition. ${ }^{3}$ In fact, the challenge is to design optimal policies that achieve the best combination of equity and efficiency.

It was clear that to achieve the economic and social aims of the Lisbon Agenda, the social model in EU-countries needed to be modernized. To ensure long-term sustainability of the social security systems in the light of the aging process, participation rates should be increased.

The Treaty of Nice of 2001 took the social agenda forward. It was agreed to advance social policy on the basis of the open method of coordination, first employed with respect to employment policies. The method recognizes that social policy remains the responsibility of member states, under the principle of subsidiarity. It implies that member states define and evaluate common objectives and learn from each other how to reach these objectives. Best practices are disseminated and benchmarking is used. Coordination is based on evaluation and

\footnotetext{
${ }^{2}$ Recommendations of the European Commission 92/441/EEC and 92/442/EEC.

3 See Boadway and Keen (2000). Empirical research indicates that inequality is negatively associated with growth; see Alesina and Rodrik (1994).
} 
peer pressure, but does not offer the option of sanctions. In Nice it was decided that member states should implement action plans for combating poverty and social exclusion and to define common objectives on social indicators. The indicators encompass financial poverty, income inequality, long-term unemployment, regional variation in employment rates, life expectancy and poor health.

Some consider these common indicators and the national action plans for social inclusion as significant progress towards integration along the social dimension. ${ }^{4}$ Others question this form of coordination. ${ }^{5}$ At least, this new mode of governance and the Lisbon agenda in general, have renewed the debate on poverty reduction in EU member states.

2.2 Combating poverty. In September/October 2006, member states adopted renewed National Action Plans for Social Inclusion under the new streamlined open method of coordination (OMC) as one chapter of the National Report on Strategies for Social Protection and Social Inclusion. They presented the key priorities in member states' efforts to promote greater social inclusion and make a decisive impact on the eradication of poverty and social exclusion (European Commission, 2007). A year later, the Commission gave special attention to the poverty among vulnerable groups, especially children, in their most recent Joint Report on Social Protection and Social Inclusion 2008 (European Commission, 2008). In most member states children are at greater risk of poverty than is the overall population. In some countries more than 25 percent of children are at risk. In general, the Report indicates that social inclusion and social protection remains high on the political agenda for most member states. Some member states have reinforced their commitments by setting quantitative targets to reduce poverty (p.101).

Progress of social inclusion and of poverty reduction is monitored considering the performance in each member state on the basis of national indicators. In the European Union people are said to be in income poverty if their incomes are below 60 per cent of the median disposable income of households in their country, after adjusting for household size (equivalence scales). ${ }^{6}$ Based on this EU-criterion, the proportion of the EU-population who were at risk of poverty in 2005 was 16 percent. This means that around 72 million citizens were

\footnotetext{
${ }^{4}$ For example, Atkinson (2002).

${ }^{5}$ Among others, Leibfried (2002).

${ }^{6}$ The evolution of the European Union will lead increasingly to question poverty-issues in a EUwide perspective, about both Europe-wide data and the underlying concepts (Atkinson, 2002, p. 626). Up till now EU-wide estimates of poverty played no role. A paper of Brandolini (2006) provides the first estimates of poverty in the enlarged European Union as if it were a single country.
} 
considered as at risk of poverty in the EU25. ${ }^{7}$

The poverty problem is also striking in other highly-developed welfare states. Industrialized countries spend a large share of their income on social security, but poverty and social exclusion have not been eradicated. A sizeable proportion of the population lives in economic poverty in all industrial welfare states. According to the most common standards used in international poverty analyses, on average roughly one in ten households live in relative poverty in OECD countries. ${ }^{8}$ The persistence of poverty in industrial welfare states calls for an explanation. If these welfare states offer elaborate systems of income maintenance, why is there still a considerable amount of poverty? Why are some countries more effective than others in this respect? What can explain these variations in effectiveness?

\section{Research design}

This paper will assess the relationship between welfare state effort and poverty alleviation in two steps. First we have to address the question of whether there is a correlation between the size of the welfare state and the incidence of poverty. Are high social expenditure rates associated with low poverty rates? Next we turn to the reduction of poverty rates through taxes and transfers and its relationship to welfare state effort. Our research design starts with the data to be used, because poverty rates and social expenditure rates can be collected from several sources. Next we discuss how to measure social effort and the effect of social transfers on poverty.

3.1 Measuring poverty incidence. For various reasons we use poverty rates from different databases. The official EU-indicator for social cohesion is the at-risk-ofpoverty rate after social transfers. This rate is defined as the share of persons with an equivalized disposable income below the risk-of-poverty threshold, which is set at 60 percent of the national median equivalized disposable income. For this indicator Eurostat data (ECHP/EU-SILC) are available for the period 1995-2005, but not for all member states.

For a further comparison, we will also use OECD poverty indicators: the poverty rate and the poverty gap. The OECD poverty rate is defined as the proportion of individuals with equivalized disposable income less than 50 percent of the median income. The poverty gap is the percentage difference between the average income of the poor and the 50 percent of median income poverty threshold. In this paper we will use OECD poverty data from the mid-1980's until

\footnotetext{
${ }^{7}$ Guio (2005).

${ }^{8}$ Background information on this can be found in Atkinson et al. (1995), Behrendt (2002) and Smeeding (2005).
} 
the year $2000 .^{9}$

Finally, we use also data from the Luxembourg Income Study (LIS). The LIS database contains income data files for 32 nations covering the period 1967 to 2005. We can analyze both the level and trend in poverty for a considerable period across a wide range of nations.

Following international standards, we use the relative rather than the absolute approach in measuring income poverty. This means that we define as poor those households that have an equivalent disposable income below a certain threshold representing the level of well-being of the population in a specific country. In our empirical analysis we use several thresholds for a poverty line (40 percent, 50 percent, and 60 percent), because the absolute number and also the structure of poverty differ dramatically depending on the threshold chosen. ${ }^{10}$ In most comparative studies the poverty threshold has been set at 50 percent of median equivalent disposable income, but we focus especially on the EU's definition of the poverty line. For comparison, the official United States poverty line was just about 30 percent of median United States disposable post-tax household income in 2007 . $^{11}$

It should be noted that there have been controversial arguments regarding the issues in the measurement of poverty. These arguments have their own merits and shortcomings, and there has been little professional consensus among research with regard to the theoretical superiority of a particular way of measuring poverty. ${ }^{12}$ Moreover, the availability of reliable data restricts the possibilities for

9 Based on Förster and Mira d'Ercole (2005). Recently OECD (2008) published their study 'Growing unequal? Income distribution and poverty in OECD countries' recent data on poverty rates across countries up till the mid-2000s In future research we will incorporate these data as well in our analyses.

10 Hagenaars and De Vos (1987) applied eight definitions for a poverty line to a 1983 household survey for the Netherlands: four definitions based on an absolute approach, three on a subjective and one a relative measure. The derived overall poverty rates ranged from 5.7 to 33.5 percent.

${ }^{11}$ U.S. Census Bureau's Current Population Survey reports for 2007 a poverty threshold for a 4person family (weighted average) of $\$ 21,203$; median disposable income for 4-person families amounts to $\$ 69,654$. It should be noted that the U.S. poverty threshold is based on an absolute poverty standard, which remains fixed over time in real terms. According to U.S. poverty definition, 12.5 percent of the population was living in poverty in 2007. The U.S. official measure of poverty is typically in the form of the cost of a basket of goods and services required to assure minimum living conditions and indexed for price changes over time. While the threshold is adjusted annually based on inflation using the Consumer Price Index (CPI-U), the measure is absolute and has been essentially unchanged since it was developed by Mollie Orshansky at the United States Social Security Administration in 1964. The poverty threshold estimates the rate of poverty in the United States by determining the number of households whose annual income is below the set threshold for the household's size. The determination of poverty is made based solely on income and cash benefits. Non-cash benefits, such as food stamps and housing subsidies, are not included in the determination of a household's poverty.

${ }^{12}$ Haveman (2008). 
conducting empirical research, which is especially problematic in cross-national studies. The aim of this paper is not to review definitional issues that arise in assessing the extent of, and change in, poverty in western industrialized countries. We simply refer to a vast literature on the sensitivity of measured results regarding the choice of income definitions, poverty lines, appropriate equivalence scales, and other elements that may affect results in comparative poverty research. $^{13}$

3.2 Measuring social effort. The overall result of quantitative studies seems to be that there is strong negative correlation between poverty and social expenditures across European countries over the last 25 years. ${ }^{14}$ We use social expenditure data from the most recent OECD Social Expenditure Database (2007). This database contains aggregate and disaggregated data on social expenditures. The main social policy areas included are old age, survivors, family and other social programs. Both cash benefits and benefits in kind are included. In this study we will perform several tests both at the aggregate level and at the program level. It should be noted that social expenditure indicators at the aggregate level have their limitations: changes in expenditure ratios may not be caused by policy changes, but simply by the number of beneficiaries as a result of an ageing population or changes in unemployment levels due to cyclical factors (see also section 3.4) ${ }^{15}$.

To indicate whether it is Europeanization rather than globalization that has had any impact on poverty (and/or social expenditures), we include not only EU member states, but also other OECD-countries. These non-EU15 countries control for the effects of globalization. ${ }^{16}$

Other problems with social expenditure as an indicator for differences in social protection across countries are related to differences in the public/private mix in the provision of social protection and differences in tax features. Adema ${ }^{17}$ has developed indicators that aim to measure what part of an economy's domestic production recipients of social benefits really draw upon, net total social expenditure. This requires capturing private social benefits and the impact of tax

\footnotetext{
13 Among others, see Atkinson (1987 and 2003), Hagenaars and De Vos (1987), Förster (1993), Atkinson et al. (1995), Behrendt (2000), Gottschalk and Smeeding (1997 and 2000), Smeeding et al. (2000), Marcus and Danziger (2000), Atkinson and Brandolini (2001), Caminada and Goudswaard (2001), Förster and Pearson (2002), Smeeding (2005), Guio (2005), Förster and Mira d'Ercole (2005), and (other) papers listed in our reference section using data from the Luxembourg Income Study. See Bourguignon et al. (2002) for a more elaborated paper on the evaluation of poverty impact of economic policies.

${ }^{14}$ Behrendt (2002).

15 Kühner (2007).

${ }^{16}$ It should be mentioned that European non-EU27 countries as Switzerland or Norway may also be influenced by European integration, for example via policy competition.

${ }^{17}$ Adema (2001).
} 
systems on social effort. For private programs to be considered 'social', they need to have a social purpose and contain an element of interpersonal redistribution and/or compulsory participation. ${ }^{18}$ The distinction between public and private social protection is made on the basis of whoever controls the relevant financial flows. Private social benefits may be important for our analysis. In so far as they contain an element of redistribution they may also have an impact on poverty levels. For example, private but mandatory pensions (in the second pillar) may have an effect on poverty incidence among the elderly. However, the impact of private social benefits is likely to be smaller than the impact of public social transfers.

The impact of the tax system on the social effort is threefold. In some countries cash benefits are taxable as a rule, in other countries they are not. In the former countries net social effort is less than suggested by gross spending indicators. Indirect taxation of consumption by benefit recipients is another factor that may blur the picture. When indirect taxes are higher, benefit recipients have less effective purchasing power. Also, the tax system can be used for social purposes. Tax deductions (e.g. family tax allowances) replace direct expenditures in some cases. The Earned Income Tax Credit in the United States is a good example of a tax break, which has the features of a social protection program. To control for the impact of tax systems on social spending, we will use the OECD data on net social expenditure. Unfortunately, these data only cover a relatively short time period (1993-2003) and are not available for all EU member states.

The most recent figures for the net social expenditure as percentage of GDP, based on the 2007 edition of the Net Social Expenditure data, indicate that accounting for the impact of taxes and of private social expenditure has an equalizing effect on levels of social effort across countries. ${ }^{19}$

3.3 Measuring the effects of taxes and transfers. Usually the impact of social policy on income poverty is calculated in line with the work of Musgrave, Case and Leonard, ${ }^{20}$ i.e. statutory or budget incidence analysis. Important issues of tax/transfer shifting and behavioral responses are ignored. ${ }^{21} \mathrm{~A}$ standard analysis of the anti-poverty effect of taxes and income transfers is to compare pre-tax-

\footnotetext{
${ }^{18}$ Private social programs can be mandatory or voluntary. Mandatory private benefits are often incapacity related. For example, in several countries employers are obliged to provide sickness benefits. Occupational injuries and accidents ('risque professionel') can also be covered by mandatory private insurances. A number of EU member states have supplementary employmentbased pension plans with mandatory contributions, based on a funding system. Voluntary private social security covers a wide range of programs, of which private pension plans and private social health insurance constitute major components.

${ }^{19}$ See Caminada and Goudswaard (2005) for details.

${ }^{20}$ Musgrave, Case, Leonard (1974).

${ }^{21}$ See for a critical survey of efforts to measure budget incidence by Smolensky et al. (1987)
} 
transfer poverty and post-tax-transfer poverty. To compare the antipoverty effectiveness of taxes and income transfers among western welfare states, poverty rates will be decomposed into the level of market-generated poverty, the overall level of welfare efforts, and the poverty reduction efficiency of taxes and transfers. ${ }^{22}$

A comparison between the standard at-risk-of-poverty rate and the hypothetical situation where social transfers are absent, other things being equal, shows that such transfers have an important redistributive effect that helps to reduce the number of people who are at risk of poverty. ${ }^{23}$ In the absence of all social transfers, the average poverty risk for EU member states would be considerably higher than it is in reality. It should however be noted that the indicator of poverty risk before social transfers must be interpreted with caution. ${ }^{24}$ First, no account is taken of measures that, like social cash transfers, can have the effect of raising the disposable incomes of households and individuals; namely transfers in kind, tax credits and tax allowances. Second, the pre-transfer poverty risk is compared to the post-transfer risk keeping all other things equal - namely, assuming unchanged household and labor market structures, thus disregarding any possible behavioral changes that the situation of absence of social transfers would involve. Kim showed that both the generosity and efficiency of the tax/transfer system may influence the level of pre-tax-transfer poverty. So this standard approach overestimates the antipoverty effectiveness of generous and/or targeted welfare systems.

3.4 Tests on the linkages between social protection and poverty. National preferences for social protection differ substantially across countries. AngloSaxon countries especially do not seem to be prepared to sustain the high protection levels prevailing in other countries with the same level of income. This may be an expression of cultural differences within the group of OECD countries. These differences could point to variance in the antipoverty nature of social systems as well. Anglo-Saxon welfare states (especially the United States) rely more heavily on social arrangements as far as pensions, health care and other programs are concerned. However, private social programs may generate a more limited redistribution of resources than public ones, and tax advantages towards private pension and health plans are more likely to benefit the rich. Private employment-related social benefits mostly re-allocate income between the (formerly) employed population. The same holds for fiscal advantages related to, for example, supplementary private pension plans. In general, we do expect that

\footnotetext{
${ }^{22}$ Cf. Kim (2000a).

${ }^{23}$ Among others, see Behrendt (2002), Smeeding (2005), Förster and Pearson (2002), Guio (2005) and Förster and Mira d'Ercole (2005).

${ }^{24}$ Kim (2000b) and Nell (2005).
} 
private schemes will generate less antipoverty effects than public programs.

We perform a cross-county analysis of the relationship between public and private social expenditures and poverty rates at one point in time. The material presented is only descriptive and does not explain poverty levels and poverty structure. Such an analysis should ideally be based on a theory, which would have to address at least the following cross-national differences: differences in labor markets that affect earnings of individual household members; demographic differences, such as the aging of the population and growth of single parent households, which affect both family needs and labor market decisions; and differences across countries in tax and transfers policies that not only affect family income directly, but also may affect work and investment decisions. ${ }^{25}$ Two recent seminal books edited by Kakwani and Silber in 2007 and 2008 present the panorama of the many dimensions of poverty from various disciplines. A fullyfledged model should be developed to assess the relative performance of social factors and the economic development. Such a comprehensive approach is far beyond the scope of this paper. We simply employ bi-variate regressions on the relationship between social expenditures and poverty rates, so one could argue that omitted (macroeconomic) variables cause bias. Differences in social effort across countries at one point in time can be the result of cyclical factors.

Another important point to keep in mind is that, while several other strategies can be chosen to alleviate poverty we only analyze the impact of transfers. In fact, several EU member states are increasingly emphasizing strategies to facilitate labor force participation of lower income groups. ${ }^{26}$ This may also be an effective strategy to tackle poverty.

\section{Poverty rates: some descriptive statistics}

4.1 Poverty level. Figure 1 reports poverty profiles for 30 industrialized countries around the year 2001. Data are taken from LIS. In order to account for different intensities of poverty, three different poverty lines are applied. Households are deemed to live in 'extreme poverty' if their income remains below a poverty line of 40 percent of median equivalent income; a poverty line of 50 percent demarcates 'severe poverty', whereas households with an income between 40 and 50 percent of median equivalent income are considered as living in 'moderate poverty'. Households whose income exceeds the poverty line of 50 percent, but remains below 60 percent of median equivalent income are considered as living 'in poverty'. In Figure 1 countries are ranked according to their poverty rate at the 60 percent level, while the shading of the bars shows different intensities of poverty or low income.

${ }^{25}$ Cf. Gottschalk and Smeeding (2000, p.263).

${ }^{26}$ European Commission (2008, p.101). 
Figure 1: Percent of poverty for total population in 30 countries, around 2001

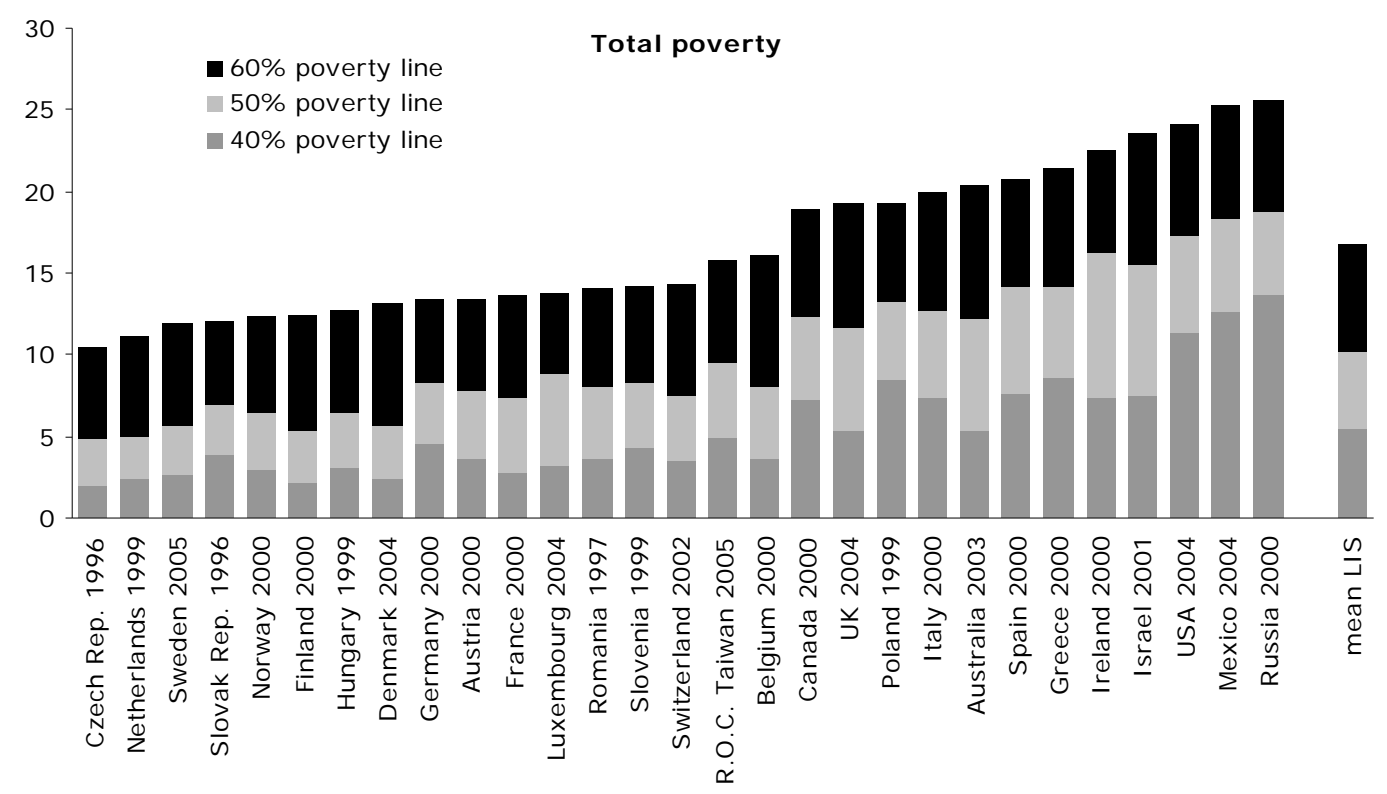

Note: Poverty rates are measured as the proportion of individuals with equivalized disposable income less than 40,50, and 60 percent of the median income of the entire population.

Source: own calculations based on LIS Key figures (www.lisproject.org)

Note that a considerable share of the population lives in relative income poverty in all industrialized welfare states, yet with a large variation of poverty rates and structure across countries. All industrialized countries in this sample display poverty rates between a range of 10.5 to 25.6 percent of the household population if the poverty line is set at 60 percent of median equivalent household income. The lowest poverty rate is found in the Czech Republic, followed by the Netherlands, Sweden, Slovak Republic, Norway, and Finland. At the very bottom of this ranking, we find the United States, Mexico and Russia with a poverty rate of almost a quarter of the household population. ${ }^{27}$

When large proportions of the population are clustered just around the threshold of 60 percent, small changes in their income can lead to large changes in poverty. To examine the sensitivity of results to alternative choices of the poverty line, Figure 1 also shows poverty rates measured with lower thresholds. It turns out that, in all OECD countries reviewed, a significant share of the

\footnotetext{
${ }^{27}$ Notten and De Neubourg (2007) estimates, according to the Orshansky-methodology for years 1996 and 2000, show also a high poverty rate for the United States compared to most European countries; however, Greece, Spain and Portugal have figures four times higher than the United States. It should be noted that their result is rather sensitive for the purchasing power parity rates used to convert the U.S. poverty lines to country specific thresholds of EU15.
} 
population is clustered between the 50 and 60 percent thresholds. This explains also why poverty statistics from the OECD (with a threshold of 50 percent) are much lower compared to the official EU-indicator (with a threshold of 60 percent of median equivalized income).

Other poverty indices would alter the country-ranking to some extent. However, the relative poverty patterns found here correspond roughly to the results found in other cross-national comparisons of poverty using income data from the LIS database and/or OECD. ${ }^{28}$ In spite of differences in the measurement of poverty and the databases used, these studies have consistently found that there is a large difference in the extent of poverty among welfare states. In general, Scandinavian and Benelux countries have the lowest poverty rates, followed by continental European countries. Anglo Saxon welfare states have relatively higher poverty rates. Among them, the extent of poverty is highest in the United States.

4.2 Poverty over time. Next, we illustrate trends in several poverty indicators. We employ both the poverty indicator used by the EU and poverty indicators from the OECD. Remarkably, according to the EU-indicator, poverty barely declined on average between 2000 and 2005. Poverty rates after social transfers even rose in Denmark, Ireland, Luxembourg, and Spain during this period. ${ }^{29}$

\footnotetext{
${ }^{28}$ See Kim (2000a).

${ }^{29}$ This result should be interpreted with caution, because there is a disruption in the time series of poverty indicators presented in Table 1. Until 2001, data were provided by the European Community Household Panel survey (ECHP). Since 2005 all EU-15 countries provide data from the new European Union Statistics on Income and Living Conditions (EU-SILC). During the transitional period poverty indicators were provided by national sources which were harmonized ex-post as closely as possible with EU-SILC definitions by Eurostat. Despite the fact that most EU-SILC variables are defined in the same way as the corresponding ECHP variables, some differences arise; see Guio (2005). See for more details the paper on 'The continuity of indicators during the transition between ECHP and EU-SILC' from Eurostat (2005).
} 
Poverty \& Public Policy, Vol. 1 [2009], Iss. 2, Art. 5

Table 1: EU at-risk-of-poverty rates

\begin{tabular}{l|rrrr} 
& 1995 & 2000 & 2003 & 2005 \\
\hline Austria & 13 & 12 & 13 & 12 \\
Belgium & 16 & 13 & 15 & 15 \\
Denmark & 10 & $:$ & 12 & 12 \\
Finland & $:$ & 11 & 11 & 12 \\
France & 15 & 16 & 12 & 13 \\
Germany & 15 & 10 & 15 & 13 \\
Greece & 22 & 20 & 21 & 20 \\
Ireland & 19 & 20 & 20 & 20 \\
Italy & 20 & 18 & $:$ & 19 \\
Luxembourg & 12 & 12 & 10 & 13 \\
Netherlands & 11 & 11 & 12 & 11 \\
Portugal & 23 & 21 & 19 & 20 \\
Spain & 19 & 18 & 19 & 20 \\
Sweden & $:$ & $:$ & $:$ & 9 \\
United Kingdom & 20 & 19 & 18 & 19 \\
\hline Mean EU15 Members (14) & 16.5 & 15.5 & 15.2 & 15.6 \\
Standard deviation & 4.11 & 3.90 & 3.66 & 3.85 \\
Coefficient of variation & 0.248 & 0.252 & 0.241 & 0.230 \\
\hline
\end{tabular}

Note: EU15 (14) are all EU15 countries excluding Sweden

Source: Structural Indicators EU - Social Cohesion (Eurostat: ECHP/EU-SILC); and own calculations.

Using the OECD definition, poverty rates in the EU even show a rather substantial increase from the mid-1980s until 2000 (Table 2). Poverty rates rose in 75 percent of EU-countries: Austria, Finland, Germany, Greece, Ireland, Italy, Luxembourg, Netherlands, and the United Kingdom.

Our trend findings on relative poverty use half of median income as the definition of poverty, and our findings are similar to those in other recent LIS papers with different percentage of median poverty rates and a less wide range of countries. In general, relative poverty is higher in most nations at the end of the period compared to the beginning. Several member states (Austria, Germany, Ireland, Italy, Netherlands, and the United Kingdom) experienced a rapid increase in relative poverty over this period. 
Caminada and Goudswaard: Effectiveness of Poverty Reduction in the EU

Table 2: OECD poverty rates

\begin{tabular}{|c|c|c|c|c|c|}
\hline & $\begin{array}{r}\text { Mid- } \\
1980 \mathrm{~s} \\
\end{array}$ & $\begin{array}{r}\text { Mid- } \\
1990 \mathrm{~s}\end{array}$ & 2000 & $\begin{array}{r}\text { Change } \\
2000- \\
\text { mid- } \\
1980 \mathrm{~s}\end{array}$ & $\begin{array}{r}\text { Change } \\
2000- \\
\text { mid- } \\
1990 \mathrm{~s}\end{array}$ \\
\hline Australia & 12.2 & 9.3 & 11.2 & -1.0 & 1.9 \\
\hline Austria & 6.1 & 7.4 & 9.3 & 3.2 & 1.9 \\
\hline Canada & 11.6 & 9.5 & 10.3 & -1.3 & 0.8 \\
\hline Denmark & 5.3 & 3.8 & 4.3 & -1.0 & 0.6 \\
\hline Finland & 5.1 & 4.9 & 6.4 & 1.3 & 1.5 \\
\hline France & 8.0 & 7.5 & 7.0 & -0.9 & -0.4 \\
\hline Germany & 6.4 & 9.1 & 9.8 & 3.4 & 0.6 \\
\hline Greece & 13.4 & 13.9 & 13.5 & 0.1 & -0.3 \\
\hline Ireland & 10.6 & 11.0 & 15.4 & 4.8 & 4.4 \\
\hline Italy & 10.3 & 14.2 & 12.9 & 2.6 & -1.3 \\
\hline Japan & 11.9 & 13.7 & 15.3 & 3.3 & 1.6 \\
\hline Luxembourg & 5.4 & 5.5 & 5.5 & 0.1 & -0.1 \\
\hline Mexico & 20.7 & 21.7 & 20.3 & -0.4 & -1.5 \\
\hline Netherlands & 3.1 & 6.3 & 6.0 & 2.9 & -0.3 \\
\hline New Zealand & 5.8 & 7.8 & 10.4 & 4.6 & 2.6 \\
\hline Norway & 6.9 & 8.0 & 6.3 & -0.6 & -1.7 \\
\hline Sweden & 6.0 & 3.7 & 5.3 & -0.7 & 1.6 \\
\hline Turkey & 16.4 & 16.2 & 15.9 & -0.5 & -0.3 \\
\hline United Kingdom & 6.9 & 10.9 & 11.4 & 4.5 & 0.5 \\
\hline United States & 17.9 & 16.7 & 17.1 & -0.9 & 0.4 \\
\hline Mean OECD-20 & 9.5 & 10.1 & 10.7 & 1.2 & 0.6 \\
\hline Standard deviation & 4.7 & 4.6 & 4.4 & -0.3 & -0.2 \\
\hline Coefficient of variation & 0.492 & 0.461 & 0.414 & -0.077 & -0.048 \\
\hline Mean EU15 Members & 7.2 & 8.2 & 8.9 & 1.7 & 0.7 \\
\hline Standard deviation & 2.8 & 3.5 & 3.6 & 0.8 & 0.0 \\
\hline Coefficient of variation & 0.384 & 0.428 & 0.399 & 0.015 & -0.029 \\
\hline
\end{tabular}

Notes:

- Poverty rates are measured as the proportion of individuals with equivalized disposable income less than 50 percent of the median income of the entire population.

- "2000" data refer to the year 2000 in all countries except 1999 for Australia, Austria and Greece; 2001 for Germany, Luxembourg, and New Zealand; and 2002 for Mexico and Turkey; "Mid-1990s" data refer to the year 1995 in all countries except 1993 for Austria; 1994 for Australia, Denmark, France, Germany, Greece, Ireland, Japan, Mexico and Turkey; and 1996 for New Zealand; "Mid-1980s" data refer to the year 1983 for Austria, Denmark and Sweden; 1984 for Australia, France, Italy and Mexico; 1985 for Canada, Japan, the Netherlands, Spain and the United Kingdom; 1986 data for Finland, Luxembourg, New Zealand and Norway; 1987 for Ireland and Turkey; 1988 for Greece; and 1989 for the United States.

Source: OECD Poverty Indicator Data based on Förster and Mira d'Ercole (2005); and own calculations. 
The number of people with a low income is only one way of measuring poverty. Another relevant measure is the intensity of poverty. The poverty gap measures the percentage difference between the average income of the poor and the 50 percent of median income poverty threshold. Also, these OECD equity data are available from the mid-1980's until the year $2000 .{ }^{30}$ Note that the poverty gap has on average been reduced in the EU from the mid-1980s until 2000. But the reduction of the poverty gap has been larger in OECD-countries outside the EU.

Table 3: OECD poverty gap

\begin{tabular}{|c|c|c|c|c|c|}
\hline & Mid-1980s & Mid-1990s & 2000 & $\begin{array}{r}\text { Change } \\
2000 \text { - mid- } \\
1980 \mathrm{~s}\end{array}$ & $\begin{array}{r}\text { Change } \\
2000-\text { mid- } \\
1990 \mathrm{~s}\end{array}$ \\
\hline Australia & 24.2 & 31.5 & 26.7 & 2.5 & -4.8 \\
\hline Austria & 27.6 & 20.7 & 30.0 & 2.3 & 9.3 \\
\hline Canada & 19.8 & 29.9 & 32.0 & 12.2 & 2.0 \\
\hline Denmark & 22.1 & 25.6 & 24.1 & 2.0 & -1.5 \\
\hline Finland & 25.9 & 21.8 & 20.7 & -5.2 & -1 . \\
\hline France & 32.9 & 23.4 & 25.8 & -7.1 & 2. \\
\hline Germany & 22.9 & 23.6 & 31.7 & 8.8 & 8 \\
\hline Greece & 32.8 & 29.9 & 29.7 & -3.0 & -0.2 \\
\hline Ireland & 23.0 & 12.0 & 24.0 & 1.0 & 12.0 \\
\hline Italy & 29.9 & 37.2 & 36.5 & 6.6 & -0.7 \\
\hline Japan & 0.0 & 35.0 & 36.1 & 36.1 & 1. \\
\hline Luxembourg & 18.1 & 17.7 & 17.3 & -0.7 & -0 . \\
\hline Mexico & 36.4 & 37.1 & 36.0 & -0.4 & -1 . \\
\hline Netherlands & 32.4 & 27.3 & 29.4 & -3.0 & 2 \\
\hline New Zealand & 34.2 & 29.1 & 23.3 & -10.9 & -5.8 \\
\hline Norway & 22.5 & 28.1 & 28.2 & 5.7 & 0.1 \\
\hline Sweden & 40.2 & 30.7 & 26.1 & -14.2 & -4.6 \\
\hline Turkey & 29.2 & 28.6 & 27.8 & -1.4 & -0 . \\
\hline United Kingdom & 16.0 & 19.6 & 22.9 & 6.9 & 3. \\
\hline United States & 33.6 & 34.1 & 34.7 & 1.1 & 0 . \\
\hline Mean OECD-20 & 26.2 & 27.5 & 28.1 & 2.0 & 1.0 \\
\hline Standard deviation & 8.7 & 6.5 & 5.2 & -3.5 & -1.3 \\
\hline Coefficient of variation & 0.333 & 0.239 & 0.185 & -0.149 & -0.054 \\
\hline Mean EU15 Members & 27.0 & 24.1 & 26.5 & -0.5 & 2. \\
\hline Standard deviation & 6.7 & 6.4 & 5.0 & -1.7 & -1 . \\
\hline Coefficient of variation & 0.249 & 0.264 & 0.189 & -0.060 & -0.07 \\
\hline
\end{tabular}

Notes: continued on next page

Notes for Table 3:

${ }^{30}$ Based on Förster and Mira d'Ercole (2005). 
- Poverty gaps are measured as the percentage difference between the average income of the poor and the 50 percent of median income poverty threshold.

- "2000" data refer to the year 2000 in all countries except 1999 for Australia, Austria and Greece; 2001 for Germany, Luxembourg, and New Zealand; and 2002 for Mexico and Turkey; "Mid1990s" data refer to the year 1995 in all countries except 1993 for Austria; 1994 for Australia, Denmark, France, Germany, Greece, Ireland, Japan, Mexico and Turkey; and 1996 for New Zealand; "Mid-1980s" data refer to the year 1983 for Austria, Denmark and Sweden; 1984 for Australia, France, Italy and Mexico; 1985 for Canada, Japan, the Netherlands, Spain and the United Kingdom; 1986 data for Finland, Luxembourg, New Zealand and Norway; 1987 for Ireland and Turkey; 1988 for Greece; and 1989 for the United States.

'Source: OECD Poverty Indicator Data based on Förster and Mira d'Ercole (2005); and own calculations

Finally, we present figures of the trend in poverty based on LIS-data for the period 1979-2005. It should be noted that the specific time interval varies by country, because LIS does not contain data for every country each year. Nonetheless, LIS is well suited to compare the trend in poverty over time because of the high quality of the comparability of the data due to their extensive data collection method. Table 4 presents the poverty rates of the national population in the early 1980s and around 2005, using the EU's current definition of poverty 60 percent of median disposable income adjusted for family size. 
Poverty \& Public Policy, Vol. 1 [2009], Iss. 2, Art. 5

Table 4: Poverty for total population in 30 countries, 1979-2005 (poverty line $60 \%$ median income)

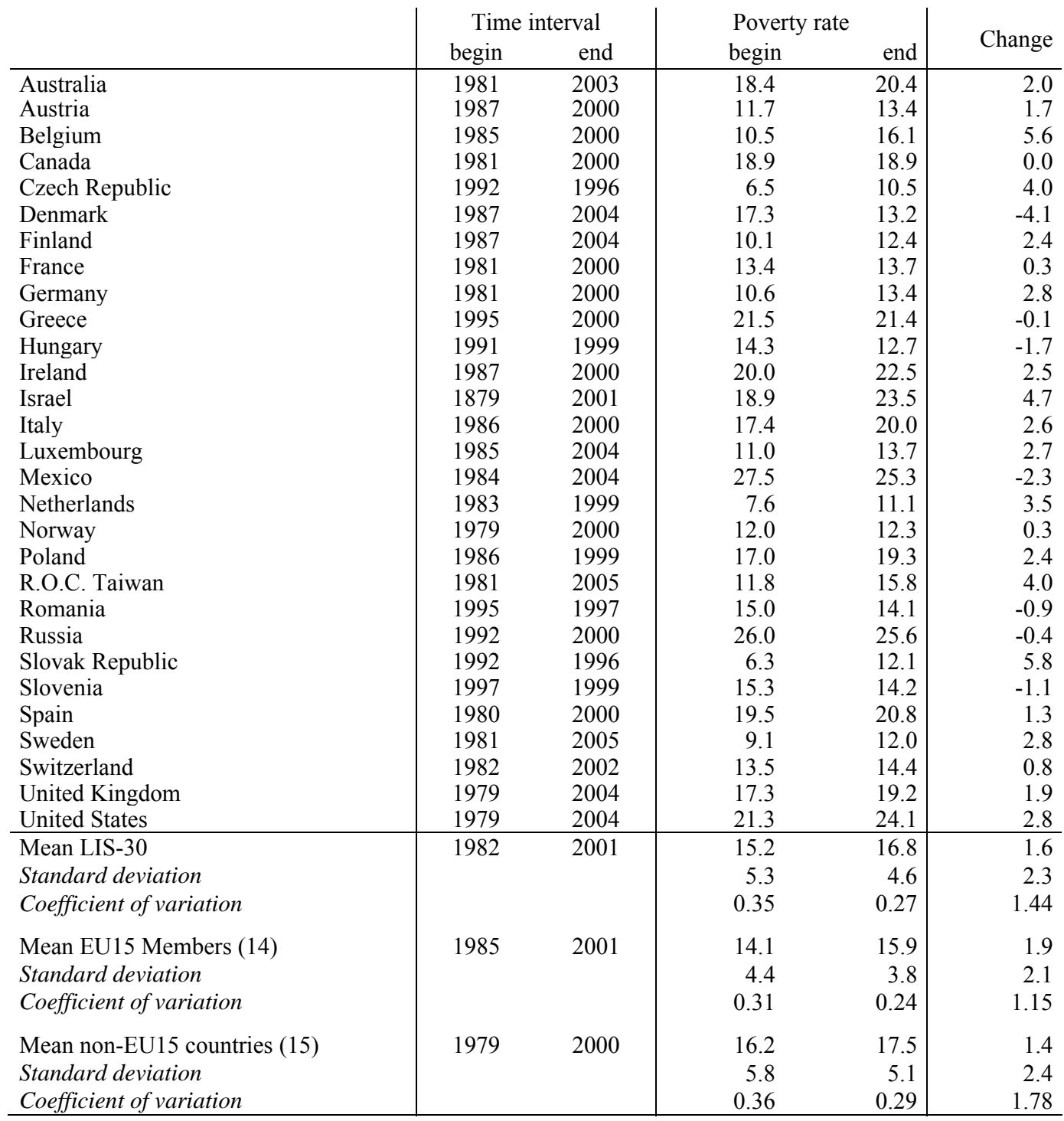

Source: own calculations based on LIS Key figures (www.lisproject.org) 
Poverty rates across the 30 selected LIS-countries (applying a 60 percent threshold to calculate poverty rates) increased on average with 1.6 percentage points during this period. Over time cross-country differences did not alter much on average. However, in some countries poverty rose at a remarkably high speed (over 3 percentage points): the Netherlands, Czech Republic, Taiwan, Israel, Belgium, and Slovak Republic.

Country clustering based on poverty rates is quite different from that of welfare state regimes. Among the countries with low poverty rates we find representatives of the social democratic regime and the corporatist regime. Likewise the nations with higher rates of poverty represent several regime types and both members of the EU15 and the new member states.

4.3 Vulnerable groups: Decomposition of poverty by age groups. Now we turn to groups typically over-represented among the poor - the vulnerable for whom social programs are supposed to guarantee a minimum income. We are particularly interested in how the social transfers affect their poverty status. For each of the vulnerable groups, we report their poverty rates and then assess the impact of transfers on their poverty rates.

Figure 2 reports poverty profiles for children and elderly for 30 industrialized countries based on LIS-data. Again, three different poverty lines are applied (40, 50 and 60 percent of equivalized median income). Countries are ranked according to their poverty rate at the 60 percent level; the shading of the bars show different intensities of poverty or low income.

On average, across all countries, around 18.4 percent of all children fell below the 60 percent poverty threshold around 2001 . Child poverty rates are especially low in the Nordic countries, where fewer than 10 percent of all children are poor. Child poverty is high in Mexico, the United States, and Russia (around 30 percent), but also in Italy, Ireland, Spain, and the United Kingdom, where it is above 20 percent. In most countries, relative poverty rates among children are also higher than for the entire population (compare Figure 1 with Figure 2), but with much variation across countries. These differences suggest that specific factors increase risks of poverty for children in some OECD countries. ${ }^{31}$

${ }^{31}$ Cf. Förster and Mira d'Ercole (2005). 
Figure 2: Poverty rates children and elderly in 30 countries, around 2001

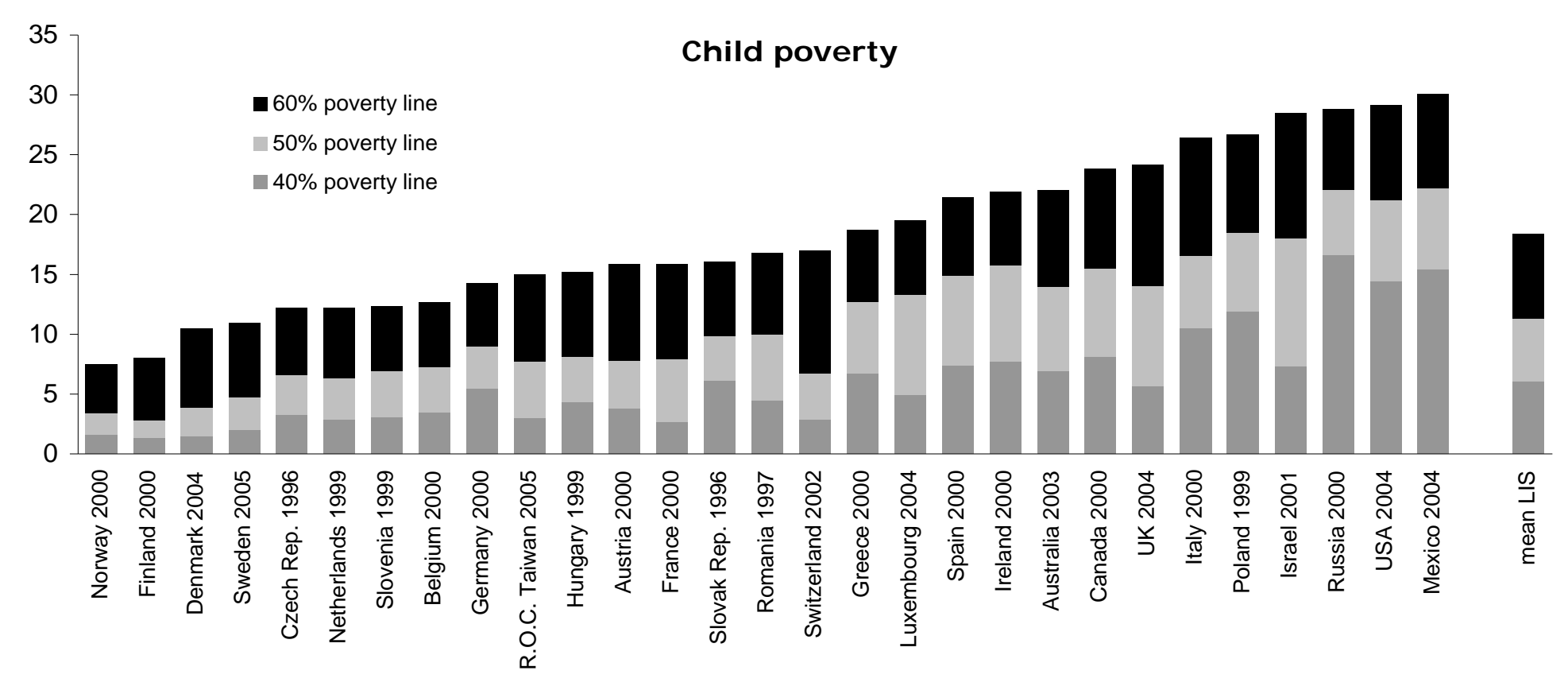


Figure 2, continued: Poverty rates children and elderly in 30 countries, around 2001

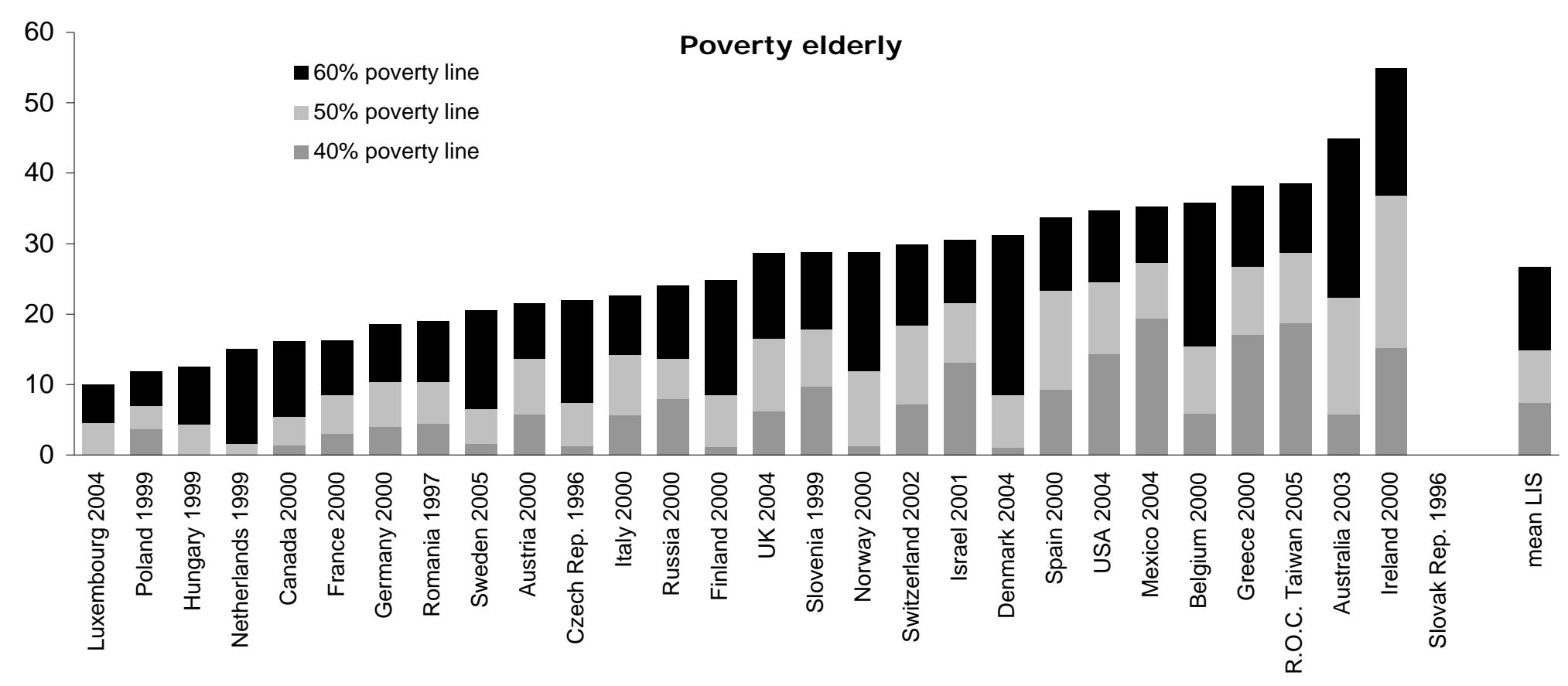

Note: Poverty rates are measured as the proportion of individuals with equivalized disposable income less than 40,50 , and 60 percent of the median income of the entire population.

Source: own calculations based on LIS Key figures (www.lisproject.org) 
Traditionally the elderly are also seen as a vulnerable group, because their economic wellbeing largely depends on the social protection system. On average, across all countries, 26.7 percent of the elderly live in poverty (60 percent threshold) which is almost twice as high as the average of total population. Crosscountry differences are large, with relatively good figures for Luxembourg, Poland, Hungary, and the Netherlands. In several countries poverty exceeds $1 / 3$ of the elderly: in the United States, Mexico, Belgium, Greece, Taiwan, Australia, and Ireland.

To sum up, our analysis of poverty of vulnerable groups identifies serious holes in the safety net of several countries. In several member states the safety net offers little assistance to vulnerable groups. ${ }^{32}$ On average, child poverty is a lesser problem than is the poverty of elderly in these nations. But single parents and their children generally have the highest poverty rates, while those in two-parent units, mixed units, and the childless experience the least poverty.

\section{Welfare state effort and the alleviation of poverty: an empirical analysis}

5.1 Linkages between poverty rates and gross social spending. Traditionally, welfare state typologies have been largely based on the overall level of social expenditure. Quantitative studies have found a strong negative relationship between poverty rates and the level of social expenditure over the last 25 years; this finding has now been well established in empirical studies. ${ }^{33}$ In other words, countries with a higher level of welfare expenditure are likely to have lower poverty rates.

Figure 3 illustrates that there is indeed a strong significant correlation between the level of gross public social expenditure as a percentage of GDP in 2003 and poverty rates across countries around the year $2000(\rho<0.01)$. Countries with higher gross public social expenditure ratios in 2003 tend to have lower poverty rates than countries with lower expenditure ratios. So, our simple linkage exercise does confirm the general finding that more social spending generates less poverty across countries. However, our results are less clear cut than earlier findings. We find an effect which is less strong in EU-countries compared to nonEU15 countries, possibly under the influence of welfare state reforms. ${ }^{34}$ This result does not depend on the poverty line applied (40,50 or 60-percent-ofmedian-income poverty threshold); see Figure 3. Moreover, we did a sensitivity

\footnotetext{
${ }^{32}$ Cf. Sainsbury and Morissens (2002).

${ }^{33}$ See Förster (1993), Kenworthy (1999), Kangas and Palme (2000), Kim (2000a), Sainsbury and Morissens (2002), Cantillon et al. (2002), Behrendt (2002), Förster and Pearson (2002), Brady (2004), Scruggs and Allen (2005), Smeeding (2005), Förster and Mira d'Ercole (2005), and Pestieau (2006, pp.16-17).

${ }^{34} \mathrm{Cf}$. Adelantado and Caldéron Cuevas (2006).
} 
analysis with the OECD poverty data and found the same result: higher gross public social expenditure ratios generate less poverty across countries, although this effect is less strong in EU-countries compared to non-EU15 countries.

Figure 3: Linkage between gross public social expenditure and LIS poverty rates across 19 countries, around 2000-2003.

\section{Non-EU15 countries}

$40 \%$ poverty line

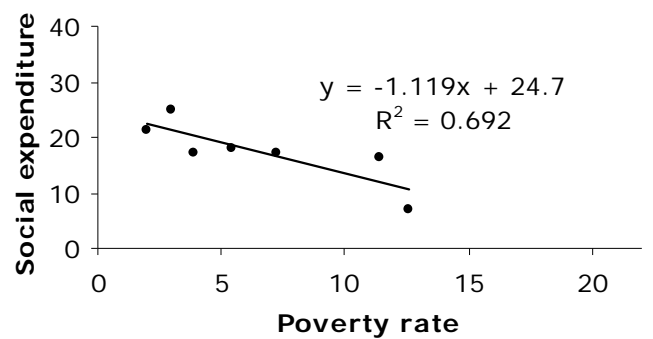

$50 \%$ poverty line

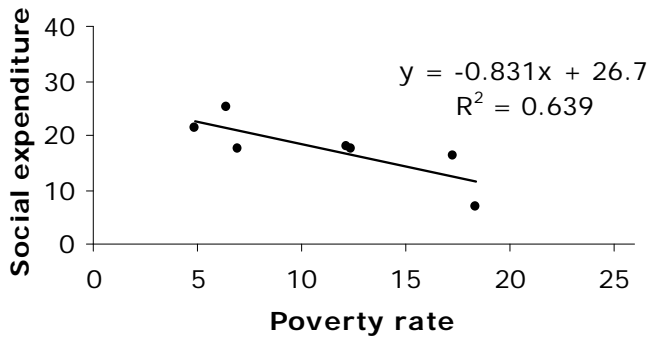

$60 \%$ poverty line

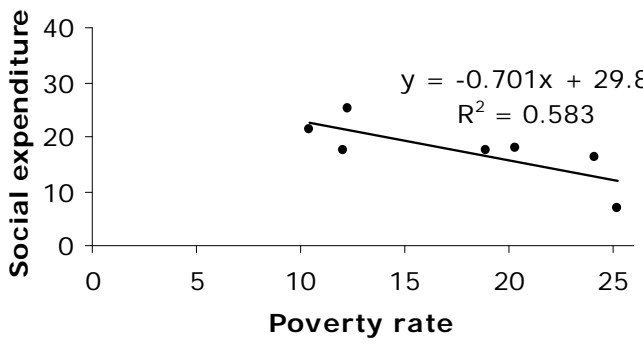

Non-EU15 countries: Australia, Canada, Czech

Republic, Mexico, Norway, Slovak Republic, and the United States

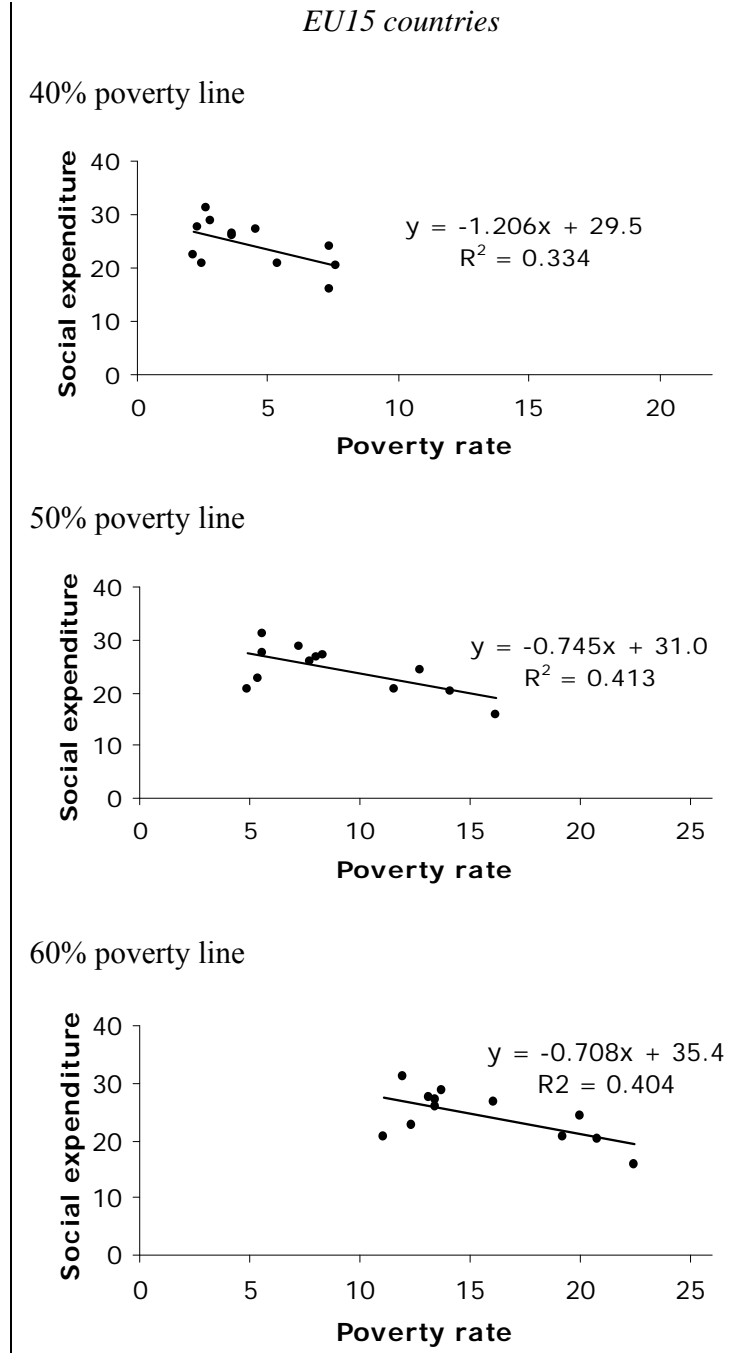

EU15 countries: Austria, Belgium, Denmark, Finland, France, Germany, Ireland, Italy, Netherlands, Spain, Sweden, and the United Kingdom

Source: Net Social Expenditure, 2007 edition from http://www.oecd.org/dataoecd/14/23/38143827.xls; LIS Key figures from http://www.lisproject.org; and own calculations 
5.2 The impact of the tax system. Up till now, our results support the conventional view that extensive social-welfare programs reduce poverty. However, these findings may be influenced by ignoring the impact of the tax system. In Figure 4 we have corrected the expenditure ratios for the impact of the tax system, using the OECD data mentioned earlier. We have linked the poverty rates across countries around the year 2000 to net social expenditures of 2003. We again apply the 40-, 50-, and 60-percent-of median income poverty thresholds, and we use LIS-data on poverty.

Figure 4: Linkage between net public social expenditure and LIS poverty rates across 19 countries, 2000-2003

\section{Non-EU15 countries}

$40 \%$ poverty line

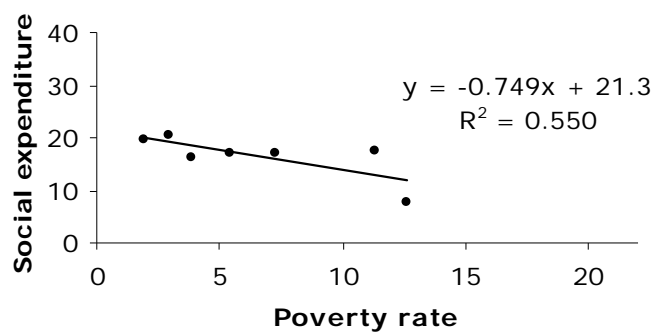

$50 \%$ poverty line

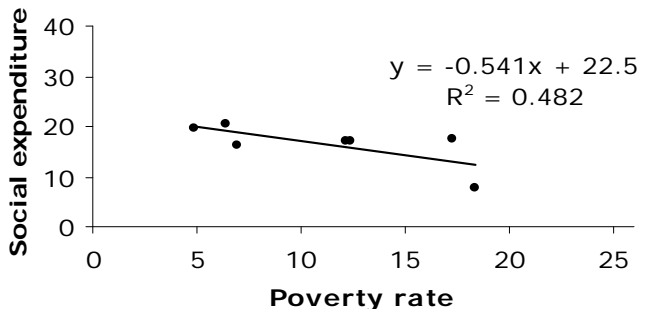

$60 \%$ poverty line

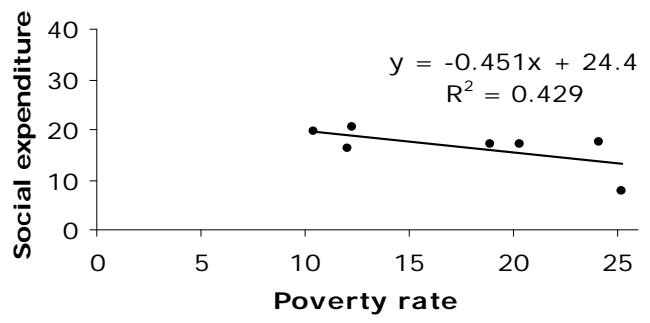

Non-EU15 countries: Australia, Canada, Czech Republic, Mexico, Norway, Slovak Republic, and the United States
EU15 countries

$40 \%$ poverty line

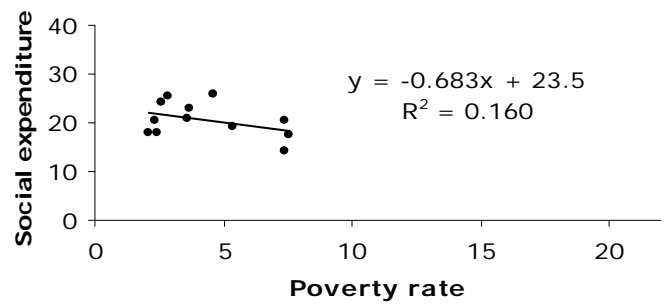

$50 \%$ poverty line

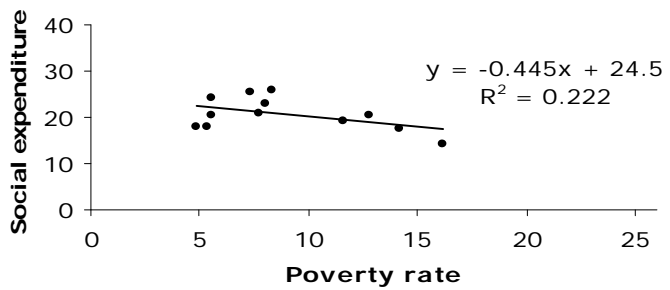

$60 \%$ poverty line

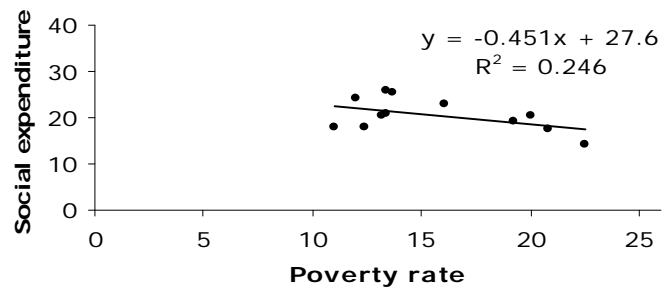

EU15 countries: Austria, Belgium, Denmark, Finland, France, Germany, Ireland, Italy, Netherlands, Spain, Sweden, and the United Kingdom

Source: Net Social Expenditure, 2007 edition from http://www.oecd.org/dataoecd/14/23/38143827.xls; LIS Key figures from http://www.lisproject.org; and own calculations

DOI: $10.2202 / 1944-2858.1023$ 
At one moment in time, the linkage effect of net public social expenditure ratios and poverty rates across countries turns out to be less strong compared to the effect of gross public spending (lower correlation coefficients $\mathrm{R}^{2}$ in all cases). Moreover, in case social expenditures are corrected for the impact of tax systems, we do not find a significant (negative) correlation for both the EU15 countries and the non-EU15 countries separately. Only for all countries together we still find a fit $(\rho<0.01)$.

We conclude that the conventional view that welfare spending goes along with less poverty must at least be mitigated. The linkage between the two variables becomes substantially weaker if the expenditure data are corrected for relevant tax features, which gives a more realistic picture.

5.3 The impact of private social expenditure. Another problem with social expenditure as an indicator for differences in social protection across countries is related to variations in the public/private mix in the provision of social protection. In Figure 5 we have included private social arrangements in our social expenditure indicator for 2003, using the OECD data as developed by Adema (2001). We have linked the poverty rates across countries around 2000 to net total social expenditures of 2003. For this plot, we apply the 60-percent-of median income poverty threshold, and we use LIS-data on poverty.

Figure 5: Linkage between net total social expenditure and LIS poverty rates across 19 countries, around 2000-2003

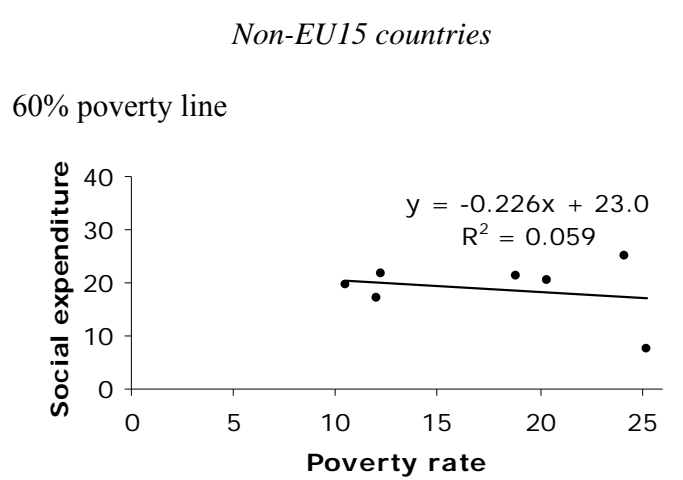

Non-EU15 countries: Australia, Canada, Czech Republic, Mexico, Norway, Slovak Republic, and the United States

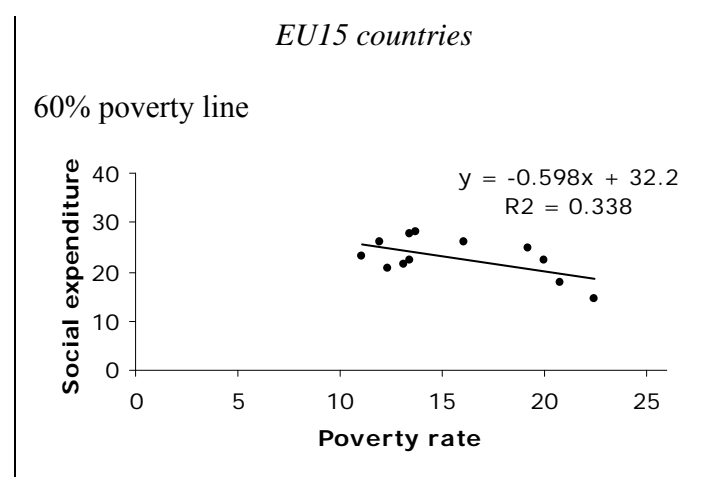

EU15 countries: Austria, Belgium, Denmark, Finland, France, Germany, Ireland, Italy, Netherlands, Spain, Sweden, and the United Kingdom

Source: Net Social Expenditure, 2007 edition from http://www.oecd.org/dataoecd/14/23/38143827.xls; LIS Key figures from http://www.lisproject.org; and own calculations. 
The results alter considerably in case private social expenditure are included as well. For non-EU15 countries in our sample we do not find any evidence for a negative correlation between the level of net total social spending and the incidence of poverty $\left(\mathrm{R}^{2}=0.059\right)$. Since there is no clear and strong negative link, more social spending does not offer an easy route to less poverty within these countries. In contrast, for the group of EU15 countries we find a significant fit $\left(\mathrm{R}^{2}=0.338 ; \rho<0.05\right)$. Private social expenditure does seem to matter as far as poverty alleviation in the EU is concerned. ${ }^{35}$ Apparently, private social arrangements have more redistributive impact in the EU than in other OECD countries.

Table 5 summarizes our results. It shows the correlation coefficients and significance of all linkages between social expenditure and poverty rates across countries in case different poverty lines and /or data sets are employed. This sensitivity analysis shows more or less the same results in case other poverty lines and/or other databases for poverty are applied (LIS or OECD). However, the results are sensitive for the social indicator used. Note that we find rather good fits for gross social expenditures, both for non-EU15 and EU15 countries. However, the effect of the tax systems alters the picture. Still we find a significant negative relationship between net public spending and poverty rates for all countries, but not for EU15 countries or non-EU15 countries separately. For the EU15 we do find a fit again if we include private social expenditure. For the EU15, private social benefits do seem to help to reduce poverty levels. However, the linkage between net total social expenditure and poverty levels is still much weaker than in the case the traditional indicator gross public social spending is used.

\footnotetext{
35 An OLS-regression shows a coefficient for private social expenditure of -1.214 (R2=0.44; $\rho<0.02)$.
} 
Caminada and Goudswaard: Effectiveness of Poverty Reduction in the EU

Table 5: Correlation coefficient and significance of linkages between social expenditure and poverty rates across countries around 2000-2003

\begin{tabular}{l|c|c|c} 
& $\begin{array}{c}\text { Non-EU15 } \\
\text { countries }\end{array}$ & EU15 countries & All countries \\
\hline Gross public social expenditure & $0.692 *$ & $0.334 *$ & $0.549 * *$ \\
- Poverty line 40, LIS data & $0.639 *$ & $0.413 *$ & $0.506 * *$ \\
- Poverty line 50, LIS data & $0.772 * *$ & $0.362 *$ & $0.616 * *$ \\
- Poverty line 50, OECD data & $0.538 *$ & $0.403 *$ & $0.454 * *$ \\
- Poverty line 60, LIS data & $0.550--$ & $0.160--$ & $0.405 * *$ \\
\hline Net public social expenditure & $0.482--$ & $0.222-$ & $0.370 * *$ \\
- Poverty line 40, LIS data & $0.527--$ & $0.125-$ & $0.396 * *$ \\
- Poverty line 50, LIS data & $0.429--$ & $0.246--$ & $0.345 * *$ \\
- Poverty line 50, OECD data & & & \\
- Poverty line 60, LIS data & $0.121--$ & $0.279-$ & $0.243 *$ \\
\hline Net total social expenditure & $0.079--$ & $0.346-$ & $0.231 *$ \\
- Poverty line 40, LIS data & $0.193--$ & $0.205-$ & $0.293 *$ \\
- Poverty line 50, LIS data & $0.059--$ & $0.338 *$ & $0.193-$ \\
- Poverty line 50, OECD data & - Poverty line 60, LIS data & & \\
\hline
\end{tabular}

Note:

- OLS-regression; ** Social expenditure variable significant at the 0.01 level; * Social expenditure variable significant at 0.05 level, -- Social expenditure variable insignificant at 0.05 level.

Source: see Appendix

\section{Antipoverty effect of social transfers and taxes}

6.1 Introduction. In every nation, benefits from governments and net of taxes reduce relative income poverty. The first columns of Table 6 show relative poverty rates calculated for household market income, rather than the earlier calculations that used disposable income after transfers and taxes. Table 6 compares the different at risk-of-poverty rates before and after social transfers and taxes. In each country, these rates are calculated with the same threshold, namely the nationally-defined 60 percent threshold calculated on the basis of total household income, i.e. including all social transfers. 
Poverty \& Public Policy, Vol. 1 [2009], Iss. 2, Art. 5

Table 6: EU at-risk-of-poverty rate before and after social transfers and taxes, 1995-2005

\begin{tabular}{l|rrr|rrr} 
& \multicolumn{3}{|c|}{ Before social transfers and taxes } & \multicolumn{3}{c}{ After social transfers and taxes } \\
& 1995 & 2000 & 2005 & 1995 & 2000 & 2005 \\
\hline Austria & 24 & 22 & 24 & 13 & 12 & 12 \\
Belgium & 27 & 23 & 28 & 16 & 13 & 15 \\
Denmark & $:$ & $:$ & 31 & 10 & $:$ & 12 \\
Finland & $:$ & 19 & 28 & $:$ & 11 & 12 \\
France & 26 & 24 & 26 & 15 & 16 & 13 \\
Germany & 22 & 20 & 24 & 15 & 10 & 13 \\
Greece & 23 & 22 & 23 & 22 & 20 & 20 \\
Ireland & 34 & 31 & 32 & 19 & 20 & 20 \\
Italy & 23 & 21 & 24 & 20 & 18 & 19 \\
Luxembourg & 25 & 23 & 23 & 12 & 12 & 13 \\
Netherlands & 24 & 22 & 22 & 11 & 11 & 11 \\
Portugal & 27 & 27 & 26 & 23 & 21 & 20 \\
Spain & 27 & 22 & 24 & 19 & 18 & 20 \\
Sweden & $:$ & $:$ & 29 & $:$ & $:$ & 9 \\
United Kingdom & 32 & 29 & $:$ & 20 & 19 & 19 \\
\hline Mean & 26.0 & 23.0 & 26.0 & 17.0 & 15.0 & 16.0 \\
Standard deviation & 3.48 & 3.37 & 3.02 & 4.11 & 3.90 & 3.85 \\
Coefficient of variation & 0.133 & 0.143 & 0.116 & 0.248 & 0.252 & 0.253 \\
\hline
\end{tabular}

Notes:

- At-risk-of-poverty rate before social transfers: the share of persons with an equivalized disposable income, before social transfers, below the risk-of-poverty threshold, which is set at 60 percent of the national median equivalized disposable income (after social transfers). In the EU data retirement and survivor's pensions are counted as income before transfers and not as social transfers, because the prime role of old age (and survivors') pensions is not to re-distribute income across individuals but rather over the life-cycle of individuals.

- At-risk-of-poverty rate after social transfers: the share of persons with an equivalized disposable income below the risk-of-poverty threshold, which is set at 60 percent of the national median equivalized disposable income

Source: Structural Indicators EU - Social Cohesion (Eurostat: ECHP/EU-SILC); own calculations

We calculate both the absolute and the relative measures of poverty reduction. The absolute antipoverty effect is the percentage point difference between the poverty rate before and after taxes and transfers. The relative effectiveness is measured as: (pre-tax-transfers poverty rate - post-tax-transfers poverty rate) / pre-tax-transfers poverty rate * 100 .

Table 6 shows pronounced differences in the performance of the social protection systems of the EU15 countries in reducing poverty. In the absence of all social transfers, the poverty risk for the EU15 population as a whole would be considerably higher than it is in reality (26 percent instead of 16 percent). Moreover, the antipoverty effect amounts 15 to 20 percent points for Nordic countries in 2005; rather poor antipoverty effects are found for Greece, Italy and Spain. 
Figure 6 illustrates a broader picture of the 'best-practices' for the EU25 countries in combating poverty. Countries are listed is descending order of the magnitude of their relative antipoverty effect of social transfers.

Figure 6: Absolute and relative poverty reduction, 2005

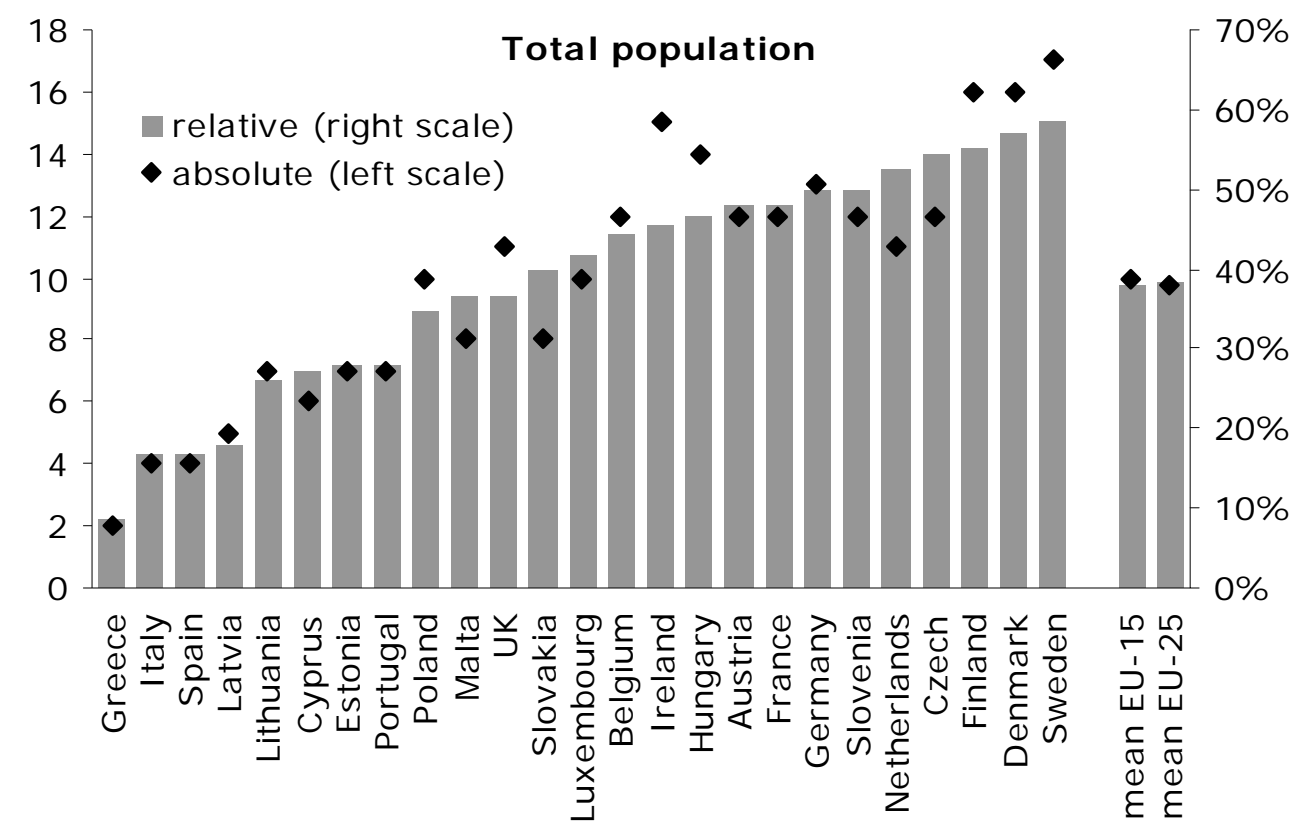

Note: In all cases the risk-of-poverty threshold (before and after social transfers and taxes) is set at 60 percent of the national median equivalized disposable income. Retirement and survivor's pensions are counted as income before transfers.

Source: Structural Indicators EU - Social Cohesion (Eurostat: EU-SILC); own calculations

Next, we also include five non-EU15 countries as a benchmark into our analysis. We calculated the antipoverty effect of social transfers and taxes, based on up-dated figures from the LIS Fiscal redistribution dataset. ${ }^{36}$ This dataset measures pre- and post-government poverty levels, using a composite measure that reflects both the headcount of those in poverty (the percentage of all persons whose equivalized household income falls below 50 percent of their country's median) and the depth of their poverty (the difference between the median income of the entire population and the mean income of the poor). Countries are listed in descending order of the magnitude of their (absolute) antipoverty effect; see Table 7 .

Remarkably enough, the United States relative poverty rate before taxes and social transfers is actually below average for the selected countries, even though

${ }^{36}$ See Mahler and Jesuit (2006). 
the United States ranks the highest of all the countries in this comparison group in relative poverty rates after taxes and transfers. Given this divergence, it should be no surprise that of the countries listed, the United States (and Ireland) devote the smallest share of its resources to antipoverty income transfer programs. ${ }^{37}$ Bestpractices at the top of this list can be found for Belgium, Germany, and the Nordic countries. Moreover, the EU15 countries show on average an antipoverty effect of 20.3 percentage points (or 80 percent), while the other non-EU15-countries produce on average a rather poor effect of 13.4 percentage points among their population (65 percent).

Table 7: Poverty scores of private sector income and disposable income

\begin{tabular}{|c|c|c|c|c|c|c|c|c|c|}
\hline \multirow[b]{2}{*}{ Country } & \multirow[b]{2}{*}{ Year } & \multicolumn{3}{|c|}{ Private sector income } & \multicolumn{3}{|c|}{ Disposable income } & \multicolumn{2}{|c|}{ Poverty reduction } \\
\hline & & $\mathrm{HC}$ & GAP & $\mathrm{HC} * \mathrm{GAP}$ & $\mathrm{HC}$ & GAP & HC*GAP & Absolute & Percent \\
\hline Belgium & 1997 & 32.0 & 0.91 & 29.0 & 8.0 & 0.63 & 5.0 & 24.0 & 83 \\
\hline Finland & 2004 & 30.3 & 0.87 & 26.2 & 6.5 & 0.60 & 3.9 & 22.3 & 85 \\
\hline Germany & 2000 & 30.9 & 0.87 & 26.8 & 8.4 & 0.63 & 5.3 & 21.5 & 80 \\
\hline Sweden & 2000 & 29.8 & 0.84 & 24.9 & 6.5 & 0.66 & 4.3 & 20.6 & 83 \\
\hline Denmark & 2004 & 28.0 & 0.86 & 24.0 & 5.6 & 0.62 & 3.5 & 20.5 & 85 \\
\hline France & 1994 & 29.5 & 0.86 & 25.3 & 8.0 & 0.61 & 4.9 & 20.4 & 81 \\
\hline UK & 1999 & 31.9 & 0.86 & 27.5 & 12.5 & 0.63 & 7.9 & 19.6 & 71 \\
\hline Ireland & 1987 & 30.4 & 0.87 & 26.6 & 11.1 & 0.64 & 7.1 & 19.5 & 73 \\
\hline Australia & 2003 & 28.6 & 0.85 & 24.4 & 12.2 & 0.64 & 7.8 & 16.6 & 68 \\
\hline Norway & 2000 & 24.9 & 0.82 & 20.3 & 6.4 & 0.64 & 4.1 & 16.2 & 80 \\
\hline Netherlands & 1999 & 21.4 & 0.82 & 17.6 & 4.9 & 0.64 & 3.1 & 14.5 & 82 \\
\hline Switzerland & 2002 & 20.7 & 0.85 & 17.5 & 7.6 & 0.63 & 4.8 & 12.7 & 73 \\
\hline Canada & 2000 & 25.2 & 0.79 & 20.0 & 12.4 & 0.65 & 8.1 & 11.9 & 60 \\
\hline USA & 2004 & 26.6 & 0.80 & 21.2 & 17.3 & 0.68 & 11.8 & 9.4 & 44 \\
\hline \multirow{3}{*}{\multicolumn{2}{|c|}{$\begin{array}{l}\text { Mean } \\
\text { Standard deviation } \\
\text { Coefficient of variation }\end{array}$}} & 27.9 & 0.85 & 23.7 & 9.1 & 0.64 & 5.8 & 17.8 & 75 \\
\hline & & & & 3.6 & & & 2.3 & 4.2 & 11.1 \\
\hline & & & & 0.15 & & & 0.40 & 0.235 & 0.15 \\
\hline \multirow{2}{*}{\multicolumn{2}{|c|}{$\begin{array}{l}\text { Mean EU15 (9) } \\
\text { Standard deviation }\end{array}$}} & 29.4 & 0.86 & 25.3 & 7.9 & 0.63 & 5.0 & 20.3 & 80 \\
\hline & & & & 3.1 & & & 1.5 & 2.5 & 4.7 \\
\hline \multicolumn{2}{|c|}{ Coefficient of variation } & & & 0.12 & & & 0.30 & 0.121 & 0.06 \\
\hline \multirow{3}{*}{\multicolumn{2}{|c|}{$\begin{array}{l}\text { Mean other OECD (5) } \\
\text { Standard deviation } \\
\text { Coefficient of variation }\end{array}$}} & 25.2 & 0.82 & 20.7 & 11.2 & 0.65 & 7.3 & 13.4 & 65 \\
\hline & & & & 2.2 & & & 2.7 & 2.7 & 12.2 \\
\hline & & & & 0.11 & & & 0.37 & 0.203 & 0.19 \\
\hline
\end{tabular}

Source: LIS Fiscal redistribution dataset based on Mahler and Jesuit (2006); updated figures from http://www.lisproject.org/publications/fiscalredistdata/fiscred.htm; and own calculations.

${ }^{37}$ Cf. Smeeding (2005). 
6.2 The impact of welfare state effort. Next we turn to the reduction of poverty rates through taxes and transfers and its relationship to welfare state effort. Table 8 presents the linkage between poverty reduction and social expenditure ratios for 16 European countries where all relevant data items are available. This gives a picture of the targeting of social protection efforts across European countries at one moment in time (around 2003-2005). Table 8 ranks countries according to their 'effectiveness' of combating poverty. Absolute antipoverty effects are divided by social spending ratios to see which country targets best per one point of GDP spent on net social expenditure. Our analysis highlights some crosscountry differences of poverty alleviation in the EU15, although the ranking must be interpreted with caution due to cyclical factors. For example, each percentage point of net total public social expenditure alleviates poverty in Ireland and the Scandinavian countries by $0.65-1.05$ percentage points, while the lowest scores can be found in Italy, Spain and Portugal (0.18-0.32). Especially the 'top' position of Ireland seems to be influenced by the recent economic performance in this particular country (high economic growth, low unemployment rates, and (therefore) the lowest level of social expenditures).

Relative to their level of net social expenditure, Sweden (26.1 percent of GDP) was expected to have a good performance in alleviating poverty. In contrast, France and Germany realize much less reduction of poverty rates, but on a markedly higher level of net social expenditure (respectively 28.0 and 27.6 percent of GDP). 
Poverty \& Public Policy, Vol. 1 [2009], Iss. 2, Art. 5

Table 8: Targeting effect of social expenditures on poverty reduction in the EU, around 2003-2005

\begin{tabular}{|c|c|c|c|c|c|c|c|c|}
\hline & \multicolumn{4}{|c|}{$\begin{array}{c}\text { Poverty rate total population, } 2005 \\
\text { (poverty line at } 60 \% \text { of median income) }\end{array}$} & \multicolumn{2}{|c|}{$\begin{array}{l}\text { Social expenditures, } \\
\quad \% \text { GDP, } 2003\end{array}$} & \multicolumn{2}{|c|}{$\begin{array}{l}\text { Targeting } \\
\text { effect }\end{array}$} \\
\hline & $\begin{array}{c}\text { Before } \\
\text { social } \\
\text { transfers } \\
\text { and taxes }\end{array}$ & $\begin{array}{c}\text { After } \\
\text { social } \\
\text { transfers } \\
\text { and } \\
\text { taxes }\end{array}$ & $\begin{array}{c}\text { Absolute } \\
\text { effect }\end{array}$ & $\begin{array}{c}\text { Relative } \\
\text { effect }\end{array}$ & $\begin{array}{l}\text { Gross } \\
\text { public }\end{array}$ & $\begin{array}{l}\text { Net } \\
\text { total }\end{array}$ & Absolute & Absolute \\
\hline & (1) & (2) & (3) & (4) & (5) & (6) & $(3):(5)$ & $(3):(6)$ \\
\hline Ireland & 33 & 18 & 15 & $45 \%$ & 15.9 & 14.3 & 0.94 & 1.05 \\
\hline Finland & 29 & 13 & 16 & $55 \%$ & 22.5 & 20.6 & 0.71 & 0.78 \\
\hline Denmark & 28 & 12 & 16 & $57 \%$ & 27.6 & 21.6 & 0.58 & 0.74 \\
\hline Sweden & 29 & 12 & 17 & $59 \%$ & 31.3 & 26.1 & 0.54 & 0.65 \\
\hline Czech Republic & 22 & 10 & 12 & $55 \%$ & 21.1 & 19.8 & 0.57 & 0.61 \\
\hline Austria & 25 & 13 & 12 & $48 \%$ & 26.1 & 22.2 & 0.46 & 0.54 \\
\hline Netherlands & 21 & 10 & 11 & $52 \%$ & 20.7 & 23.1 & 0.53 & 0.48 \\
\hline Germany & 26 & 13 & 13 & $50 \%$ & 27.3 & 27.6 & 0.48 & 0.47 \\
\hline Slovakia & 20 & 12 & 8 & $40 \%$ & 17.3 & 17.0 & 0.46 & 0.47 \\
\hline Belgium & 27 & 15 & 12 & $44 \%$ & 26.5 & 26.0 & 0.45 & 0.46 \\
\hline United Kingdom & 30 & 19 & 11 & $37 \%$ & 20.6 & 24.6 & 0.53 & 0.45 \\
\hline Luxembourg & 24 & 14 & 10 & $42 \%$ & 22.2 & n.a. & 0.45 & n.a. \\
\hline France & 25 & 13 & 12 & $48 \%$ & 28.7 & 28.0 & 0.42 & 0.43 \\
\hline Portugal & 25 & 18 & 7 & $28 \%$ & 23.5 & 22.1 & 0.30 & 0.32 \\
\hline Spain & 24 & 20 & 4 & $17 \%$ & 20.3 & 17.7 & 0.20 & 0.23 \\
\hline Italy & 24 & 20 & 4 & $17 \%$ & 24.2 & 22.3 & 0.17 & 0.18 \\
\hline Mean & 25.8 & 14.5 & 11.3 & $44 \%$ & 23.5 & 22.2 & 0.48 & 0.51 \\
\hline
\end{tabular}

Source: Structural Indicators EU - Social Cohesion (Eurostat: EU-SILC); Net Social Expenditure 2007; and own calculations

Within the group of EU-countries we do not find a significant relationship between (high) levels of social expenditure and high anti-poverty effects of social transfers and taxes; see Figure 7. Evidently, social spending is not the only determinant of a country's poverty outcome. More factors should be taken into consideration (see Kim, 2000a; and Behrendt, 2002). Market income inequality is obviously an important source of cross-national variation in poverty. Also specific differences in both the social and the tax system should be taken into account in the assessment of the antipoverty effect of welfare states. Moreover, international variations in poverty profiles are driven by variations in socio-demographic and socio-economic structures, as these factors put different restraints on income transfer schemes. And also, besides social transfers, several other policy instruments may be used to alleviate poverty. For example, several countries put relatively much emphasis on improving job opportunities and stimulating labor force participation of lower income groups. 
Caminada and Goudswaard: Effectiveness of Poverty Reduction in the EU

Figure 7: Linkage between social expenditure and relative poverty rate reduction among EUcountries, around 2003-2005
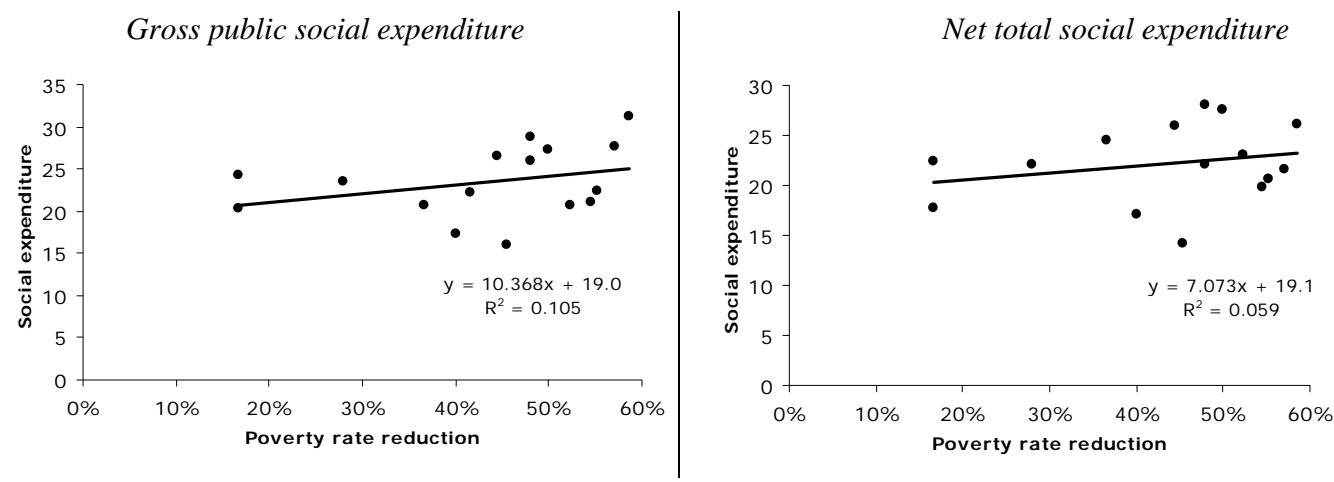

Selected countries: Austria, Belgium, Czech Republic, Denmark, Finland, France, Germany, Ireland, Italy, Luxembourg, Netherlands, Portugal, Slovakia, Spain, Sweden, and the United Kingdom

Source: Structural Indicators EU - Social Cohesion (Eurostat: EU-SILC); Net Social Expenditure 2007; and own calculations

As a benchmark we also include four non-EU15 countries into our analysis. The picture on the targeting of social transfers and taxes on poverty reduction is based upon up-dated figures from the LIS Fiscal redistribution dataset. Each percentage point of net total public social expenditure alleviates poverty in Australia and Norway by $0.75-0.92$ percentage points, while the lowest scores can be found in Canada and the United States (0.37-0.56). Especially the targeting effectiveness of the United States is remarkably low, and lies below halve of the average of all countries presented in Table 9. It should, however, be noted that these results could be sensitive to the data year chosen (around 20032005). 
Poverty \& Public Policy, Vol. 1 [2009], Iss. 2, Art. 5

Table 9: Targeting effect of social expenditures on poverty reduction, around 2000-2003

\begin{tabular}{|c|c|c|c|c|c|c|c|c|c|}
\hline & \multicolumn{5}{|c|}{$\begin{array}{c}\text { Poverty rate total population } \\
\text { (poverty line at } 50 \% \text { median income) }\end{array}$} & \multicolumn{2}{|c|}{$\begin{array}{l}\text { Social expenditures \% } \\
\text { GDP, } 2003\end{array}$} & \multicolumn{2}{|c|}{$\begin{array}{l}\text { Targeting } \\
\text { effect }\end{array}$} \\
\hline & Year & $\begin{array}{c}\text { Private sector } \\
\text { income } \\
\text { HC*GAP }\end{array}$ & $\begin{array}{l}\text { Disposable } \\
\text { income } \\
\text { HC*GAP }\end{array}$ & $\begin{array}{l}\text { Absolute } \\
\text { effect }\end{array}$ & $\begin{array}{c}\text { Relative } \\
\text { effect }\end{array}$ & $\begin{array}{l}\text { Gross } \\
\text { public }\end{array}$ & $\begin{array}{l}\text { Net } \\
\text { total }\end{array}$ & Absolute & Absolute \\
\hline & & (1) & (2) & (3) & (4) & (5) & (6) & $(3):(5)$ & $(3):(6)$ \\
\hline Ireland & 1987 & 26.6 & 7.1 & 19.5 & $73 \%$ & 15.9 & 14.3 & 1.22 & 1.37 \\
\hline Finland & 2004 & 26.2 & 3.9 & 22.3 & $85 \%$ & 22.5 & 20.6 & 0.99 & 1.08 \\
\hline Denmark & 2004 & 24.0 & 3.5 & 20.5 & $85 \%$ & 27.6 & 21.6 & 0.74 & 0.95 \\
\hline Belgium & 1997 & 29.0 & 5.0 & 24.0 & $83 \%$ & 26.5 & 26.0 & 0.91 & 0.92 \\
\hline Australia & 2003 & 24.4 & 7.8 & 16.6 & $68 \%$ & 17.9 & 20.6 & 0.93 & 0.81 \\
\hline UK & 1999 & 27.5 & 7.9 & 19.6 & $71 \%$ & 20.6 & 24.6 & 0.95 & 0.80 \\
\hline Sweden & 2000 & 24.9 & 4.3 & 20.6 & $83 \%$ & 31.3 & 26.1 & 0.66 & 0.79 \\
\hline Germany & 2000 & 26.8 & 5.3 & 21.5 & $80 \%$ & 27.3 & 27.6 & 0.79 & 0.78 \\
\hline Norway & 2000 & 20.3 & 4.1 & 16.2 & $80 \%$ & 25.1 & 21.7 & 0.65 & 0.75 \\
\hline France & 1994 & 25.3 & 4.9 & 20.4 & $81 \%$ & 28.7 & 28.0 & 0.71 & 0.73 \\
\hline Netherlands & 1999 & 17.6 & 3.1 & 14.5 & $82 \%$ & 20.7 & 23.1 & 0.70 & 0.63 \\
\hline Canada & 2000 & 20.0 & 8.1 & 11.9 & $60 \%$ & 17.3 & 21.2 & 0.69 & 0.56 \\
\hline United States & 2004 & 21.2 & 11.8 & 9.4 & $44 \%$ & 16.2 & 25.2 & 0.58 & 0.37 \\
\hline Mean & & 24.1 & 5.9 & 18.2 & $76 \%$ & 22.9 & 23.1 & 0.80 & 0.79 \\
\hline
\end{tabular}

Source: LIS Fiscal redistribution dataset based on Mahler and Jesuit (2006), updated figures, Net Social Expenditure, 2007 edition; and own calculations 
Overall, the trends of the components of post-tax-transfer poverty can be summarized as follows. In most of welfare states, pre-tax-transfer poverty has increased during the 1980s and early 1990s. Most countries have increased the size of the welfare state during the same period. However, in many cases, the increase in the size of the welfare state is not large enough to offset the increase in pre-tax-transfer poverty. As a result, post-tax-transfer poverty has also - more or less - increased in these countries. ${ }^{38}$

\section{Social policy areas}

An important critique of aggregated social expenditure data is that it is not possible to see which individual program is responsible for a specific dynamic. Therefore we show social expenditures for various programs. We look at two vulnerable age groups: children and the elderly. We present linkages of their poverty rates with social expenditures for social programs as family and child benefits, and the public old age pensions and survivor schemes.

7.1 Children. In most EU-countries, relative poverty rates among children are higher than for the entire population, but with much variation across countries. In Finland and Denmark child poverty rates are 10 percent, while a quarter of all children lives in poverty in Hungary, Italy, Latvia, Poland, Spain, and in the United Kingdom. These differences suggest that specific factors increase risks of poverty for children in some EU-countries.

We calculated both the absolute and the relative measures of poverty reduction through social transfers and taxes; see Figure 8. Greece, Spain, and Latvia produce rather poor antipoverty effects among children with their tax/transfer system (below 20 percent). The best-practices in 2005 can be found in Finland, Germany, Austria, Denmark, Sweden, France, and Slovenia with antipoverty effects over 50 percent.

${ }^{38}$ Cf. Sainsbury and Morissens (2002), Kim (2000a) and Smeeding (2005). 
Figure 8: Absolute and relative poverty 0-17 years, 2005

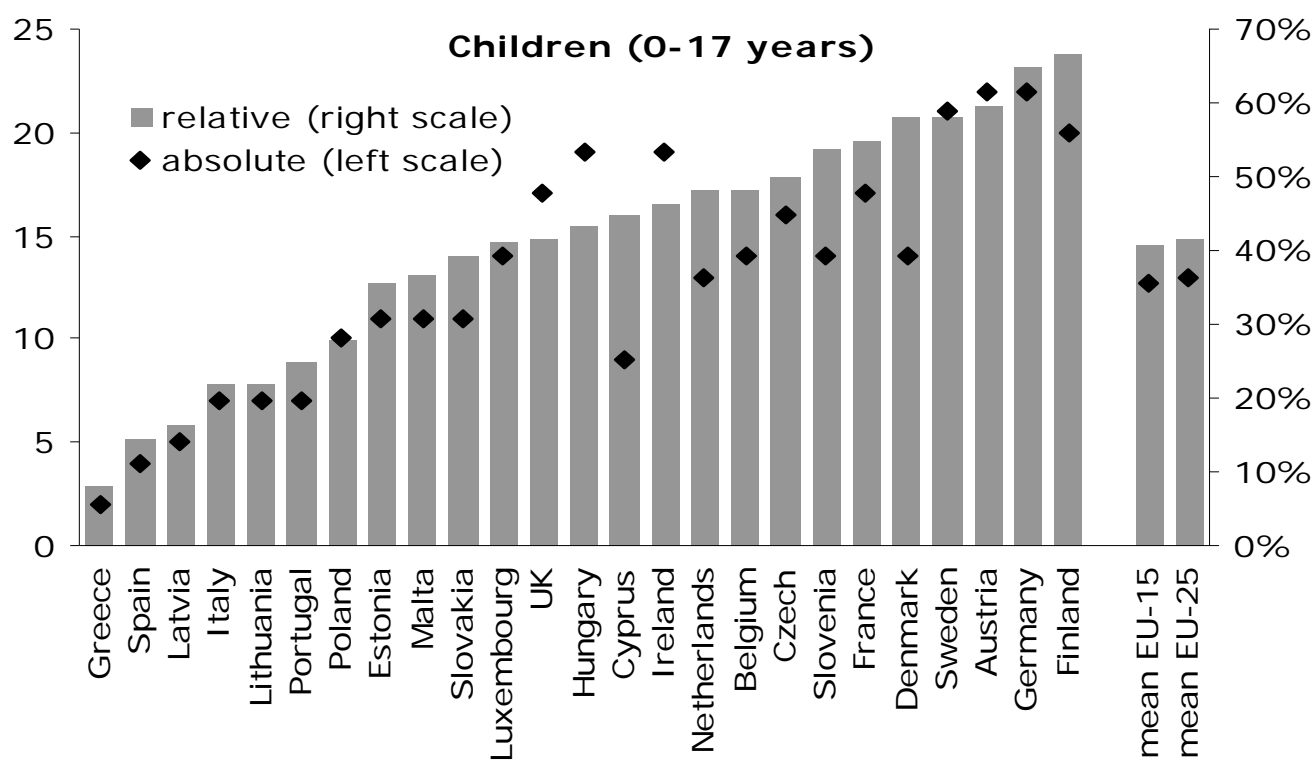

Note: In all cases the risk-of-poverty threshold (before and after social transfers and taxes) is set at 60 percent of the national median equivalized disposable income.

Source: Structural Indicators EU - Social Cohesion (Eurostat: EU-SILC); own calculations

The OECD Social Expenditure Database (SOCX) includes internationally comparable statistics on gross public social expenditure at program level. SOCX registers also family programs, i.e. expenditure which supports families (excluding one-person households). This expenditure is often related to the costs associated with raising children or with the support of other dependants. Table 10 presents the linkage between poverty reduction through the tax/transfer system, and social expenditure for family programs for EU15 countries where all relevant data items are available. This gives a picture of the targeting effectiveness of combating child poverty across European countries. However, the earlier disclaimer applies: the ranking of the countries can be influenced by country specific cyclical factors due the data year 2003-2005 chosen (relatively low/high social expenditures). 
Caminada and Goudswaard: Effectiveness of Poverty Reduction in the EU

Table 10: Targeting effect of social expenditures on child poverty reduction in the EU15, around 2003-2005

\begin{tabular}{|c|c|c|c|c|c|c|}
\hline & \multicolumn{4}{|c|}{$\begin{array}{c}\text { Poverty rate } 0-17 \text { years, } 2005 \\
\text { (poverty line at } 60 \% \text { of median income) }\end{array}$} & \multirow{3}{*}{$\begin{array}{l}\text { Gross social } \\
\text { expenditure on } \\
\text { family } \\
\text { programs, \% } \\
\text { GDP, } 2003 \\
\\
\text { (5) }\end{array}$} & \multirow{3}{*}{$\begin{array}{c}\text { Targeting } \\
\text { effect } \\
(3):(5)\end{array}$} \\
\hline & $\begin{array}{c}\text { Before social } \\
\text { transfers and } \\
\text { taxes }\end{array}$ & $\begin{array}{c}\text { After social } \\
\text { transfers and } \\
\text { taxes }\end{array}$ & $\begin{array}{c}\text { Absolute } \\
\text { effect }\end{array}$ & $\begin{array}{c}\text { Relative } \\
\text { effect }\end{array}$ & & \\
\hline & (1) & (2) & (3) & (4) & & \\
\hline Austria & 37 & 15 & 22 & $59 \%$ & 3.1 & 7.1 \\
\hline Belgium & 29 & 15 & 14 & $48 \%$ & 2.7 & 5.2 \\
\hline Denmark & 24 & 10 & 14 & $58 \%$ & 3.9 & 3.5 \\
\hline Finland & 30 & 10 & 20 & $67 \%$ & 3.0 & 6.7 \\
\hline France & 31 & 14 & 17 & $55 \%$ & 3.0 & 5.6 \\
\hline Germany & 34 & 12 & 22 & $65 \%$ & 1.9 & 11.3 \\
\hline Ireland & 41 & 22 & 19 & $46 \%$ & 2.5 & 7.5 \\
\hline Italy & 32 & 25 & 7 & $22 \%$ & 1.2 & 5.6 \\
\hline Luxembourg & 34 & 20 & 14 & $41 \%$ & 4.1 & 3.4 \\
\hline Netherlands & 27 & 14 & 13 & $48 \%$ & 1.6 & 7.9 \\
\hline Portugal & 28 & 21 & 7 & $25 \%$ & 1.6 & 4.4 \\
\hline Spain & 28 & 24 & 4 & $14 \%$ & 1.0 & 3.8 \\
\hline Sweden & 36 & 15 & 21 & $58 \%$ & 3.5 & 5.9 \\
\hline United & 41 & 24 & 17 & $41 \%$ & 2.9 & 5.8 \\
\hline Mean & 32.3 & 17.2 & 15.1 & $47 \%$ & 2.6 & 5.8 \\
\hline
\end{tabular}

Source: Structural Indicators EU - Social Cohesion (Eurostat: EU-SILC); OECD Social Expenditure Database (SOCX) based on www.oecd.org/els/social/expenditure; and own calculations

Rather good targeting figures of child poverty alleviation per point of GDP social spending can be found in Germany, followed by the Netherlands, Ireland, and Austria. Low scores can be found in Luxembourg, Denmark, and Spain. In these countries each percentage point of social expenditure on family programs alleviates poverty only by 3.4-3.8 percentage points around 2003-2005.

Next we also include Australia, Canada, Norway, Switzerland, and the United States into our analysis. Poverty rates are from LIS, and a 60-percent-ofmedian-income poverty threshold is applied. For all countries, we find a significant negative relationship between levels of social expenditure on family programs and poverty rates $\left(\mathrm{R}^{2}=0.285 ; \rho<0.02\right)$. This correlation is much stronger for non-EU15 countries $\left(R^{2}=0.469\right)$ compared with the EU15 countries $\left(R^{2}=0.163\right)$. See Figure 9. 
Figure 9: $\quad$ Linkage between gross social expenditure on family programs and LIS poverty rates among 19 countries, around 2000-2003

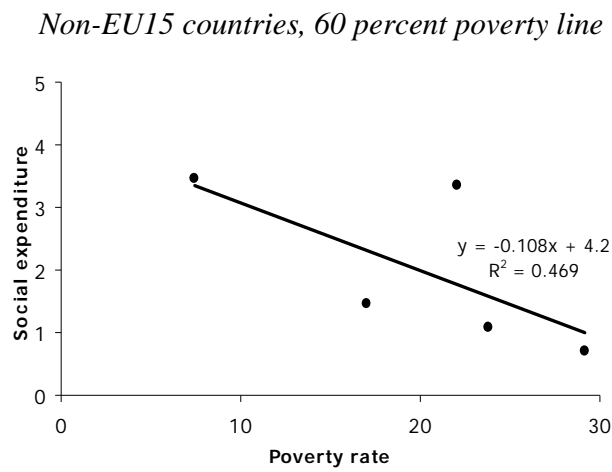

Non-EU15 countries: Australia, Canada, Norway, Norway, Switzerland, and the United States

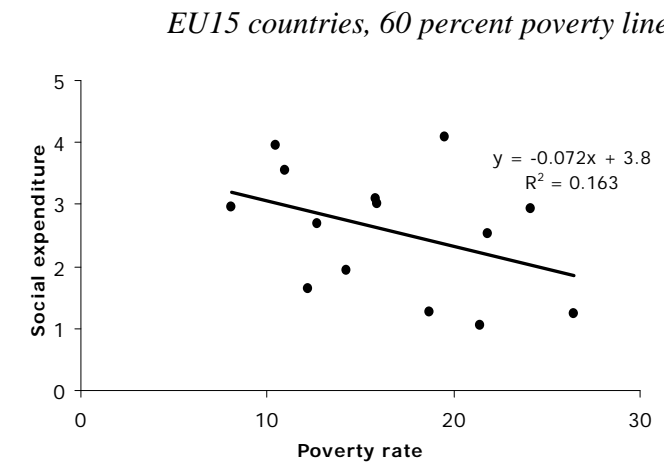

EU15 countries: Austria, Belgium, Denmark, Finland, France, Germany, Greece, Ireland, Italy, Luxembourg, Netherlands, Spain, Sweden, and the United Kingdom

Source: OECD Social Expenditure Database (SOCX) based on www.oecd.org/els/social/expenditure; LIS Key figures from http://www.lisproject.org; and own calculations

7.2 Elderly. Given their weight in the disposable income of elderly people, public pensions play a major role in shaping income adequacy and poverty risks for this group of the population. $\mathrm{Wu}(2005)$ indicates that without social old age and survivors programs more than half of the older persons would be in poverty. ${ }^{39}$ Again we use the OECD Social Expenditure Database. SOCX contains gross social expenditures both on public old age programs (pensions) and on survivor schemes. ${ }^{40}$ However, we will not present the linkage between poverty reduction

\footnotetext{
${ }^{39}$ The analyses of $\mathrm{Wu}(2005)$ is based on LIS-data for 15 selected OECD countries; a 50-percentof-median-income poverty threshold is applied.

${ }^{40}$ Old-age: comprises all cash expenditures (including lump-sum payments) on old-age pensions. Old-age cash benefits provide an income for persons retired from the labor market or guarantee incomes when a person has reached a 'standard' pensionable age or fulfilled the necessary contributory requirements. This category also includes early retirement pensions: pensions paid before the beneficiary has reached the 'standard' pensionable age relevant to the program. Excluded are programs concerning early retirement for labor market reasons which are classified under unemployment. Old-age includes supplements for dependants paid to old-age pensioners with dependants under old-age cash benefits. Old age also includes social expenditure on services for the elderly people, services such as day care and rehabilitation services, home-help services and other benefits in kind. It also includes expenditure on the provision of residential care in an institution (for example, the cost of operating homes for the elderly). Survivors: many countries have social expenditure programs in the public sphere which provide the spouse or dependent of a deceased person with a benefit (either in cash or in kind). Expenditure in this policy area has been grouped under survivors. Allowances and supplements for dependent children of the recipient of a survivors' benefit are also recorded here.
} 
through the tax/transfer system, and social expenditure for public old age pensions and survivors schemes, because the calculation of the effectiveness of combating poverty among the elderly across countries would be biased. The reason for this is that (public) pensions are considered as primary income in the EU data we use, since Eurostat argue that their role is not only to redistribute resources across income groups but also, and primarily, to redistribute income over the life-cycle of individuals and/or across generations.

Therefore we take another approach to calculate the targeting effect of social expenditures of both on public old age programs and survivor schemes on poverty rates of the elderly. Poverty rates among the elderly are taken from LIS, and a 60-percent-of-median-income poverty threshold is applied. We do not find a strong (negative) relationship between levels of social expenditure on old age and survivors schemes and the level of poverty rates across the 19 developed countries $\left(\mathrm{R}^{2}=0.103\right)$. This weak correlation is found for both the group of non-EU15 countries $\left(\mathrm{R}^{2}=0.008\right)$ and the group of EU15 countries $\left(\mathrm{R}^{2}=0.093\right)$. Despite relatively high gross public spending on old-age pensions and survivors schemes some countries experience relatively high poverty rates among the elderly, especially in Greece. Rather good figures can be found in Luxembourg, the Netherlands, and Canada. In these countries relatively low poverty rates among the elderly are combined with relatively low figures for gross public social expenditure on old age and survivors.

Figure 10: Linkage between gross social expenditure on old age and survivors programs and LIS poverty rates among 19 countries, around 2000-2003

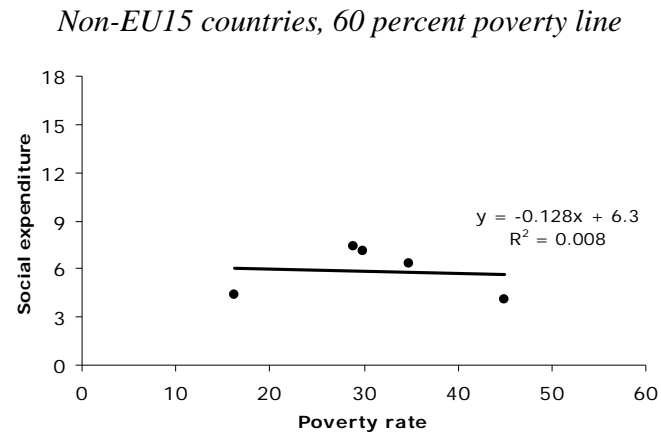

Non-EU15 countries: Australia, Canada, Norway, Norway, Switzerland, and the United States

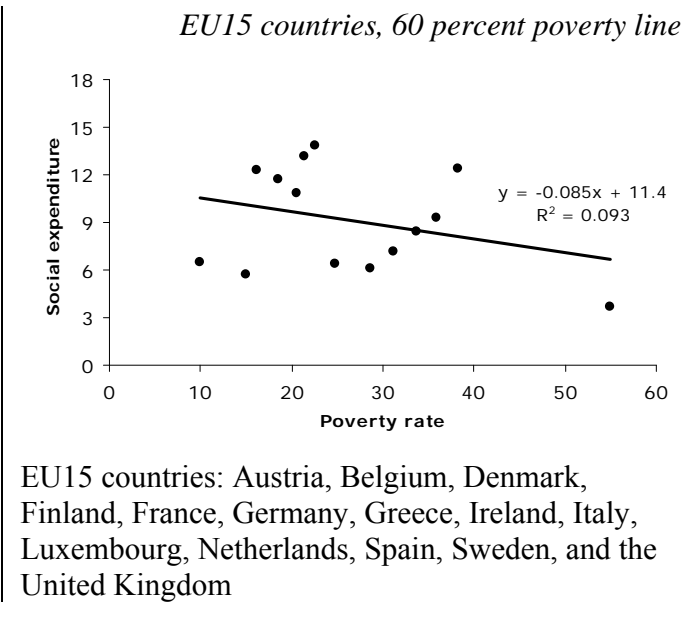

Source: OECD Social Expenditure Database (SOCX) based on www.oecd.org/els/social/expenditure; LIS Key figures from http://www.lisproject.org; and own calculations 


\section{Conclusion}

Poverty alleviation is an important objective of the EU. A wide variety of poverty rates can be found within the EU15 and EU25 countries. Some countries are more effective in poverty reduction than other countries. Remarkably enough, average at-risk-of-poverty rates - an official EU social cohesion indicator - even have risen since the adoption of the Lisbon Agenda. This suggests that recent EUinitiatives regarding combating poverty are not very effective yet. Obviously, several policy strategies may be chosen to combat poverty. This paper analyzes the effect of social transfer policies on poverty. We have done various simple bivariate tests, using several poverty definitions and several indicators for social protection.

Earlier research concluded that high social expenditure levels in welfare states are linked with low levels of poverty. Our results are less clear cut. We still find a quite strong negative relationship between poverty reduction and gross social expenditure across countries. This effect is less strong in the group of EU15 countries compared to non-EU15 countries. Sensitivity analysis shows more or less the same results in case other poverty lines and/or other databases for poverty are applied (LIS or OECD). However, the results are sensitive to the social indicator used. Taking the impact of the tax systems on expenditure statistics into account alters the picture. Still we find a significant negative relationship between net public spending and poverty rates for all countries, but not for EU15 countries or non-EU15 countries separately. This is an important result, because with this correction we have a much better measure of what governments really devote to social spending. Next, we also included private social benefits, which may also have a redistributive impact. In this case we do find a fit again for the EU15. In European countries private social arrangements do seem to help to reduce poverty levels. However, the linkage between net total social expenditure and poverty levels is much weaker than in the case the traditional indicator gross public social spending is used. Thus, the familiar claim that higher social expenditure goes along with lower poverty levels must at least be toned down to some extent.

We also analyzed the reduction of poverty rates through taxes and transfers (the difference between poverty rates calculated for market incomes and poverty rates calculated for disposable incomes) and its relationship to welfare state efforts. Within the group of EU15 countries we do not find a significant relationship between (high) levels of social expenditure and (high) antipoverty effects of social transfers and taxes. Our analysis highlights some cross-country differences in targeting of social expenditures on poverty alleviation in the EU15 around 2003-2005. Each percentage point of net social expenditure alleviates poverty in Ireland and the Scandinavian countries by $0.7-1.1$ percentage points, 
while the lowest scores can be found in Italy, Spain and Portugal (0.2-0.3). However, it should be noted that these results may be sensitive to cyclical factors.

Finally, we analyzed poverty among vulnerable age groups. Our results show that family programs and child support alleviate poverty among children to a large extent. For public old age and survivors schemes we find only a weak effect on poverty, but further research is needed on this issue.

Our results suggest that some countries are more effective than others as far as poverty reduction through social transfers is concerned. However, our descriptive analysis is too simple to draw strong conclusions upon it in terms of policy implications and policy learning. For example, the analysis does not control for differences in general economic performance and also other potential determinants of poverty are not included. A multivariate approach is needed to thoroughly assess the effectiveness of policy instruments to reduce poverty. In further research we plan to follow such an approach.

\section{Appendix: Data and correlation tests across countries}

Gross public social expenditure (\% GDP)

- OECD-22 and EU-15

- Data years: $1980-2003$

- Total

- Old age

- Survivors

- Family

- Other social policy areas

- Source: OECD Social Expenditure Database (SOCX)

- URL: www.oecd.org/els/social/expenditure

Gross and net social expenditure (\% GDP)

- OECD-24, and EU-15

- Data years: 1993, 1995, 1997, 2001, and 2003

- Gross public social expenditure

- Net public social expenditure

- Gross total social expenditure

- Net total social expenditure

- Source: Adema (2001); Adema and Ladaique (2005); Net Social Expenditure, 2007 edition

- URL: http://www.oecd.org/dataoecd/14/23/38143827.xls; 


\section{Structural Indicators EU - Social Cohesion}

- EU-15, and EU-25

- Data years: 1995, 2000, 2003, and 2005

- At-risk-of-poverty rate before social transfers

- At-risk-of-poverty rate after social transfers

- At-persistent-risk-of-poverty rate

- Source: Eurostat: ECHP/EU-SILC

- URL: http://epp.eurostat.ec.europa.eu/

\section{OECD Poverty Indicators}

- OECD-18/20, and EU-11/12

- Data years: mid-1980s, mid-1990s, 2000

- Poverty

- Poverty gap

- Source: OECD Equity Data based on Förster and Mira d'Ercole (2005)

- URL: http://www.oecd.org/dataoecd/34/11/34542691.xls

\section{LIS Key Figures on Poverty}

- Over 30 countries

- Data years: between 1979 and 2005 (over 130 LIS surveys conducted in 31 countries between 1979-2005)

- Poverty rate 40 (poverty line set at 40 percent of equivalized median income)

- Poverty rate 50 (poverty line set at 50 percent of equivalized median income)

- Poverty rate 60 (poverty line set at 60 percent of equivalized median income)

- Source: Luxembourg Income Study

- URL: http://www.lisproject.org

\section{LIS Fiscal Redistribution Dataset}

- OECD-13 (selected countries)

- Data years: between 1979 and 2002 (60 LIS surveys conducted in 13 countries between 1979-2002)

- Poverty scores pre-government private sector income

- Poverty scores post-government disposable income

- Poverty reduction

- Source: LIS data based on V.A. Mahler and D.K. Jesuit (2006); also updated figures.

- URL: http://www.lisproject.org/publications/fiscalredistdata/fiscred.htm 
Caminada and Goudswaard: Effectiveness of Poverty Reduction in the EU

Table A1: Correlation tests: Linkages between LIS poverty rates and gross and net social spending, around 2000-2003

\begin{tabular}{|c|c|c|c|c|c|c|c|c|c|c|}
\hline & \multirow{2}{*}{$\begin{array}{r}\text { Poverty } \\
\text { line }\end{array}$} & \multicolumn{3}{|c|}{ Gross public social expenditure } & \multicolumn{3}{|c|}{ Net public social expenditure } & \multicolumn{3}{|c|}{ Net total social expenditure } \\
\hline & & Intercept & $\mathrm{X} 1$ & $\mathrm{R}^{2}$ & Intercept & $\mathrm{X} 1$ & $\mathrm{R}^{2}$ & Intercept & $\mathrm{X} 1$ & $\mathrm{R}^{2}$ \\
\hline \multirow[t]{3}{*}{ Non-EU15 countries } & $40 \%$, LIS & $24.659 * *$ & $-1.119 *$ & 0.692 & $21.290 * *$ & -0.748 & 0.550 & $22.068^{* *}$ & -0.472 & 0.121 \\
\hline & & $(9.80)$ & $(-3.35)$ & $(0.631)$ & $(9.32)$ & $(-2.47)$ & $(0.460)$ & $(5.15)$ & $(-0.83)$ & $(-0.054)$ \\
\hline & & 0.000 & 0.020 & & 0.000 & 0.056 & & 0.004 & 0.444 & \\
\hline \multirow[t]{3}{*}{ EU15 countries } & $40 \%$, LIS & $29.521 * *$ & $-1.206^{*}$ & 0.334 & $23.511 * *$ & -0.683 & 0.160 & $27.247 * *$ & -1.018 & 0.279 \\
\hline & & (11.46) & $(-2.24)$ & $(0.267)$ & (9.97) & $(-1.38)$ & $(0.077)$ & (11.02) & $(-1.97)$ & $(0.207)$ \\
\hline & & 0.000 & 0.049 & & 0.000 & 0.197 & & 0.000 & 0.077 & \\
\hline \multirow[t]{3}{*}{ All 19 countries } & $40 \%$, LIS & $28.896 * *$ & $-1.393^{* *}$ & 0.549 & $23.492 * *$ & $-0.869 * *$ & 0.405 & $25.436^{* *}$ & $-0.783^{*}$ & 0.243 \\
\hline & & $(15.86)$ & $(-4.55)$ & $(0.522)$ & (15.47) & $(-3.40)$ & $(0.370)$ & (12.756) & $(-2.334)$ & $(0.198)$ \\
\hline & & 0.000 & 0.000 & & 0.000 & 0.003 & & 0.000 & 0.032 & \\
\hline \multirow[t]{3}{*}{ Non-EU15 countries } & $50 \%$, LIS & $26.715^{* *}$ & $-0.831 *$ & 0.639 & $22.502 * *$ & -0.541 & 0.482 & $22.300^{* *}$ & -0.294 & 0.079 \\
\hline & & (7.80) & $(-2.98)$ & $(0.567)$ & $(7.31)$ & $(-2.16)$ & $(0.378)$ & $(4.042)$ & $(-0.654)$ & $(-0.105)$ \\
\hline & & 0.001 & 0.031 & & 0.001 & 0.084 & & 0.010 & 0.542 & \\
\hline \multirow[t]{3}{*}{ EU15 countries } & $50 \%$, LIS & $30.976^{* *}$ & $-0.745^{*}$ & 0.413 & $24.549 * *$ & -0.445 & 0.222 & $28.474 * *$ & $-0.629 *$ & 0.346 \\
\hline & & (11.41) & $(-2.65)$ & $(0.355)$ & (9.63) & $(-1.69)$ & $(0.144)$ & (10.763) & $(-2.298)$ & $(0.280)$ \\
\hline & & 0.000 & 0.024 & & 0.000 & 0.122 & & 0.000 & 0.044 & \\
\hline \multirow[t]{3}{*}{ All 19 countries } & $50 \%$, LIS & $30.910 * *$ & $-0.935^{* *}$ & 0.506 & $24.722 * *$ & $-0.580 * *$ & 0.370 & $26.649^{* *}$ & $-0.533^{*}$ & 0.231 \\
\hline & & (12.89) & $(-4.17)$ & $(0.477)$ & (12.58) & $(-3.16)$ & $(0.333)$ & (10.54) & $(-2.26)$ & $(0.185)$ \\
\hline & & 0.000 & 0.001 & & 0.000 & 0.006 & & 0.000 & 0.037 & \\
\hline \multirow[t]{3}{*}{ Non-EU15 countries } & $60 \%$, LIS & $29.758 * *$ & $-0.701 *$ & 0.583 & $24.390 * *$ & -0.451 & 0.429 & $22.977^{*}$ & -0.225 & 0.059 \\
\hline & & $(6.06)$ & $(-2.64)$ & $(0.499)$ & $(5.66)$ & $(-1.94)$ & $(0.315)$ & $(3.09)$ & $(-0.56)$ & $(-0.129)$ \\
\hline & & 0.002 & 0.046 & & 0.002 & 0.110 & & 0.027 & 0.599 & \\
\hline \multirow[t]{3}{*}{ EU15 countries } & $60 \%$, LIS & $35.374 * *$ & $-0.708 *$ & 0.403 & $27.608 * *$ & -0.451 & 0.246 & $32.195 * *$ & $-0.598 *$ & 0.338 \\
\hline & & (8.07) & $(-2.60)$ & $(0.344)$ & $(6.87)$ & $(-1.81)$ & $(0.170)$ & $(7.56)$ & $(-2.26)$ & $(0.272)$ \\
\hline & & 0.000 & 0.026 & & 0.000 & 0.101 & & 0.000 & 0.047 & \\
\hline \multirow{3}{*}{ All 19 countries } & $60 \%$, LIS & $35.224 * *$ & $-0.822 * *$ & $0.454)$ & $27.560 * *$ & $-0.520 * *$ & 0.345 & $28.854 * *$ & -0.454 & 0.193 \\
\hline & & $(9.45)$ & $(-3.76)$ & $(0.421)$ & $(9.30)$ & $(-2.99)$ & $(0.306)$ & $(7.54)$ & $(-2.02)$ & $(0.146)$ \\
\hline & & 0.000 & 0.002 & & 0.000 & 0.008 & & 0.000 & 0.060 & \\
\hline
\end{tabular}

Notes:

- Dependent variable: LIS poverty rate (poverty line 40, 50, or 60 percent of median income).

- OLS-regression; standardized regression coefficients are reported; t-statistics in parentheses; p-value in red. ** Significant at the 0.01 level; * significant at 0.05 level.

- Correlation coefficient $\mathrm{R}^{2}$; adjusted $\mathrm{R}^{2}$ in parentheses

Selected countries: Australia, Austria, Belgium, Czech Republic, Denmark, Finland, France, Germany, Ireland, Italy, Mexico, Netherlands, Norway, Spain, Slovak Republic,

Sweden, the United Kingdom, and the United States

Source: Net Social Expenditure, 2007 edition from http://www.oecd.org/dataoecd/14/23/38143827.xls; LIS Key figures from http://www.lisproject.org; and own calculations

Published by The Berkeley Electronic Press, 2009 
Table A2: Correlation tests: Linkages between OECD poverty rates and gross and net social spending, around 2000-2003

\begin{tabular}{|c|c|c|c|c|c|c|c|c|c|c|}
\hline & \multirow[b]{2}{*}{ Poverty line } & \multicolumn{3}{|c|}{ Gross public social expenditure } & \multicolumn{3}{|c|}{ Net public social expenditure } & \multicolumn{3}{|c|}{ Net total social expenditure } \\
\hline & & Intercept & $\mathrm{X} 1$ & $\mathrm{R}^{2}$ & Intercept & $\mathrm{X} 1$ & $\mathrm{R}^{2}$ & Intercept & $\mathrm{X} 1$ & $\mathrm{R}^{2}$ \\
\hline Non-EU15 countries & $50 \%$ OECD & $\begin{array}{r}29.809 * * \\
(9.06)\end{array}$ & $\begin{array}{r}-0.986 * * \\
(-4.11)\end{array}$ & $\begin{array}{r}0.772 \\
(0.726)\end{array}$ & $\begin{array}{r}23.988^{* *} \\
(6.73)\end{array}$ & $\begin{array}{l}-0.614 \\
(-2.36)\end{array}$ & $\begin{array}{r}0.527 \\
(0.433)\end{array}$ & $\begin{array}{r}25.796^{*} \\
(3.87)\end{array}$ & $\begin{array}{l}-0.532 \\
(-1.09)\end{array}$ & $\begin{array}{r}0.193 \\
(0.031)\end{array}$ \\
\hline EU15 countries & $50 \%$ OECD & $\begin{array}{r}0.000 \\
30.879 * * \\
(1003)\end{array}$ & $\begin{array}{r}0.009 \\
-0.704 * \\
(-226)\end{array}$ & $\begin{array}{r}0.362 \\
(0291)\end{array}$ & $\frac{0.001}{23.735^{* *}}$ & $\begin{array}{r}0.065 \\
-0.337 \\
(-1.14)\end{array}$ & 0.125 & $\begin{array}{r}0.012 \\
27.185^{* *}\end{array}$ & $\begin{array}{r}0.324 \\
-0.459 \\
-152)\end{array}$ & 0.205 \\
\hline & & $\begin{array}{r}10.05) \\
0.000\end{array}$ & $\begin{array}{r}-2.20) \\
0.050\end{array}$ & & $\begin{array}{r}(8.09) \\
0.000\end{array}$ & $\begin{array}{r}(-1.14) \\
0.285\end{array}$ & & $\begin{array}{r}(33.93) \\
0.000\end{array}$ & $\begin{array}{r}(-1.52) \\
0.162\end{array}$ & \\
\hline All 18 countries & $50 \%$ OECD & $\begin{array}{r}32.678 * * \\
(13.75) \\
0.000\end{array}$ & $\begin{array}{r}-1.045^{* *} \\
(-5.07) \\
0.000\end{array}$ & $\begin{array}{r}0.616 \\
(0.592)\end{array}$ & $\begin{array}{r}25.340 * * \\
(11.70) \\
0.000\end{array}$ & $\begin{array}{r}-0.609 * * \\
(-3.24) \\
0.005\end{array}$ & $\begin{array}{r}0.396 \\
(0.358)\end{array}$ & $\begin{array}{r}27.782 * * \\
(33.48) \\
0.000\end{array}$ & $\begin{array}{r}-0.600^{*} \\
(-2.57) \\
0.020\end{array}$ & $\begin{array}{r}0.293 \\
(0.249)\end{array}$ \\
\hline
\end{tabular}

Notes:

- Dependent variable: OECD poverty rate (poverty line 50 percent of median income).

- OLS-regression; standardized regression coefficients are reported; t-statistics in parentheses; p-value in red. ** Significant at the 0.01 level; * significant at 0.05 level.

- Correlation coefficient $\mathrm{R}^{2}$; adjusted $\mathrm{R}^{2}$ in parentheses

- Selected countries: Australia, Austria, Canada, Denmark, Finland, France, Germany, Greece, Ireland, Italy, Japan, Luxembourg, Netherlands, New Zealand, Norway, Sweden, the United Kingdom, and the United States

Source: Net Social Expenditure, 2007 edition from http://www.oecd.org/dataoecd/14/23/38143827.xls; OECD Poverty Indicator Data based on Förster and Mira d'Ercole (2005); and own calculations.

\section{Table A3: Correlation tests: Linkage between social expenditure and relative poverty rate reduction among EU-countries, around 2003-2005}

Between EU-countries we do not find a significant relationship between (high) levels of social expenditure and (high) antipoverty effects of social transfers and taxes.

\begin{tabular}{|c|c|c|c|c|c|c|c|c|c|c|}
\hline & \multirow[b]{2}{*}{ Poverty line } & \multicolumn{3}{|c|}{ Gross public social expenditure } & \multicolumn{3}{|c|}{ Net public social expenditure } & \multicolumn{3}{|c|}{ Net total social expenditure } \\
\hline & & Intercept & $\mathrm{X} 1$ & $\mathrm{R}^{2}$ & Intercept & $\mathrm{X} 1$ & $\mathrm{R}^{2}$ & Intercept & $\mathrm{X} 1$ & $\mathrm{R}^{2}$ \\
\hline EU15 & $60 \%$ SILC & $\begin{array}{r}18.990^{* *} \\
(5.19) \\
0.000\end{array}$ & $\begin{array}{r}10.368 \\
(1.28) \\
0.221\end{array}$ & $\begin{array}{r}0.105 \\
(0.041)\end{array}$ & $\begin{array}{r}18.000^{* *} \\
(5.97) \\
0.000\end{array}$ & $\begin{array}{r}4.960 \\
(0.77) \\
0.454\end{array}$ & $\begin{array}{r}0.040 \\
(-0.028)\end{array}$ & $\begin{array}{r}19.124^{* *} \\
(5.39) \\
0.000\end{array}$ & $\begin{array}{r}7.073 \\
(0.91) \\
0.382\end{array}$ & $\begin{array}{r}0.059 \\
(-0.013)\end{array}$ \\
\hline
\end{tabular}

Notes:

- OLS-regression; standardized regression coefficients are reported; t-statistics in parentheses; p-value in red. ** Significant at the 0.01 level; * significant at 0.05 level.

- Correlation coefficient $\mathrm{R}^{2}$; adjusted $\mathrm{R}^{2}$ in parentheses

- Selected countries: Austria, Belgium, Czech Republic, Denmark, Finland, France, Germany, Ireland, Italy, Luxembourg, Netherlands, Portugal, Slovakia, Spain, Sweden, and the United Kingdom

Source: Structural Indicators EU - Social Cohesion (Eurostat: EU-SILC); Net Social Expenditure 2007; and own calculations 
Caminada and Goudswaard: Effectiveness of Poverty Reduction in the EU

Table A4: Correlation tests: Linkage between gross social expenditure on family programs and LIS poverty rates among 19 countries, around 20002003

We present the linkage between poverty rates for children (0-17 years) and social expenditure for family programs for all countries where all relevant data items are available.

For all countries we find a rather strong negative relationship. This correlation is much stronger for non-EU15 countries $\left(\mathrm{R}^{2}=0.469\right)$ compared with the EU15 countries $\left(\mathrm{R}^{2}=0.162\right)$

\begin{tabular}{lr|rrr|}
\cline { 3 - 5 } & Poverty line & Intercept & $\mathrm{X} 1$ & $\mathrm{R}^{2}$ \\
\hline Non-EU15 countries & $60 \%$ LIS & $4.163^{*}$ & -0.108 & 0.469 \\
& & $(2.95)$ & $(-1.63)$ & $(0.292)$ \\
& & 0.060 & 0.202 & \\
EU15 countries & $60 \%$ LIS & $3.768^{* *}$ & -0.072 & 0.162 \\
& & $(4.55)$ & $(-1.53)$ & $(0.093)$ \\
\multirow{3}{*}{ All 19 countries } & 0.001 & 0.153 & \\
& & $4.017^{* *}$ & $-0.091^{*}$ & 0.285 \\
& $60 \%$ LIS & $(6.18)$ & $(-2.60)$ & $(0.243)$ \\
& & 0.000 & 0.018 & \\
\hline
\end{tabular}

Notes:

- OLS-regression; standardized regression coefficients are reported; t-statistics in parentheses; p-value in red. ** Significant at the 0.01 level; * significant at 0.05 level.

- Correlation coefficient $\mathrm{R}^{2}$; adjusted $\mathrm{R}^{2}$ in parentheses

- Selected countries: Australia, Austria, Belgium, Canada, Denmark, Finland, France, Germany, Greece, Ireland, Italy, Luxembourg, Netherlands, Norway, Spain, Sweden, Switzerland, the United Kingdom, and the United States

Source: OECD Social Expenditure Database (SOCX) based on www.oecd.org/els/social/expenditure; LIS Key figures from http://www.lisproject.org; and own calculations 
Poverty \& Public Policy, Vol. 1 [2009], Iss. 2, Art. 5

Table A5: Correlation tests: Linkage gross social expenditure on old age and survivors programs and LIS poverty rates among 19 countries, around 2000-2003

We present the linkage between poverty rates for the elderly (65 years and over) and social expenditure for public old age pensions and survivors schemes for all countries where all relevant data items are available. There seems to be ample (negative) relationship across all countries $\left(\mathrm{R}^{2}=0.103\right)$. This insignificant correlation is found for both the group of non-EU15 countries $\left(\mathrm{R}^{2}=0.008\right)$ and the group of EU15 countries $\left(\mathrm{R}^{2}=0.093\right)$.

\begin{tabular}{lr|rrr|}
\cline { 3 - 4 } & Poverty line & Intercept & $\mathrm{X} 1$ & $\mathrm{R}^{2}$ \\
\hline Non-EU15 countries & $60 \%$ LIS & 6.262 & -0.013 & 0.008 \\
& & $(2.31)$ & $(-0.15)$ & $(-0.323)$ \\
\multirow{3}{*}{ EU15 countries } & 0.104 & 0.888 & \\
& \multirow{3}{*}{$60 \%$ LIS } & 11.370 & -0.085 & 0.093 \\
& & $(5.13)^{* *}$ & $(-1.11)$ & 0.017 \\
All 19 countries & 0.000 & 0.289 & \\
& \multirow{2}{*}{$60 \%$ LIS } & $10.794 * *$ & -0.092 & 0.103 \\
& & $(5.51)$ & $(-1.39)$ & $(0.050)$ \\
\hline
\end{tabular}

Notes:

- OLS-regression; standardized regression coefficients are reported; t-statistics in parentheses; p-value in red. ** Significant at the 0.01 level; $*$ significant at 0.05 level.

- Correlation coefficient $\mathrm{R}^{2}$; adjusted $\mathrm{R}^{2}$ in parentheses

- Selected countries: Australia, Austria, Belgium, Canada, Denmark, Finland, France, Germany, Greece, Ireland, Italy, Luxembourg, Netherlands, Norway, Spain, Sweden, Switzerland, the United Kingdom, and the United States

Source: OECD Social Expenditure Database (SOCX) based on www.oecd.org/els/social/expenditure; LIS Key figures from http://www.lisproject.org; and own calculations. 
Caminada and Goudswaard: Effectiveness of Poverty Reduction in the EU

\section{References}

Adelantado, J., and E. Calderón Cuevas. 2006. "Globalization and the welfare state: the same strategies for similar problems?", Journal of European Social Policy 16 (4), pp. 374-386.

Adema, W. 2001. "Net Social Expenditure: $2^{\text {nd }}$ edition”, Labour Market and Social Policy - Occasional Papers, No. 52, (Paris: OECD).

Adema, W. and M. Ladaique. 2005. "Net Social Expenditure, 2005 edition", OECD Social, Employment and Migration Working Paper 29, Paris: OECD.

Alesina, A. and D. Rodrik. 1994. "Distributive Politics and Economic Growth", The Quarterly Journal of Economics 109 (2), pp. 465-490.

Atkinson, A.B. 1987. "On the measurement of poverty”, Econometrica 55 (4), pp. 749-764.

Atkinson, T. 2002. "Social Inclusion and the European Union", Journal of Common Market Studies 40 (4), pp. 625-643.

Atkinson, A.B. 2003. "Income Inequality in OECD Countries: Data and Explanations", CESifo Working Paper Series No. 881.

Atkinson, A.B., L. Rainwater, and T.M. Smeeding. 1995. "Income Distribution in OECD Countries: Evidence from the Luxembourg Income Study", OECD Social Policy Studies 18, Paris.

Atkinson, A.B., and A. Brandolini. 2001. "Promise and Pitfalls in the Use of Secondary Data-Sets: Income Inequality in OECD Countries as a Case Study", Journal of Economic Literature 39 (3), pp. 771-800.

Atkinson, T., B. Cantillon, E. Marlier and B. Nolan. 2002. Social Indicators. The EU and Social Inclusion, Oxford: University Press.

Bäckman, O. 2005. "Welfare states, social structure and the dynamics of poverty rates. A comparative study of 16 countries, 1980-2000", Luxembourg Income Study Working Paper Series 408, Luxembourg.

Behrendt, Ch. 2000. "Is there income poverty in Western Europe? Methodological pitfalls in the measurement of poverty in a comparative perspective", Luxembourg Income Study Working Paper Series 258, Luxembourg. 
Behrendt, Ch. 2002. "Holes in the safety net? Social security and the alleviation of poverty in a comparative perspective", in: R. Sigg and Chr. Behrendt (eds.) Social Security in the Global Village, International Social Security Series, Volume 8, Transaction Publishers, New Brunswick / London, pp. 333-358 (also published as Luxembourg Income Study Working Paper Series 259, Luxembourg).

Boadway, R., and M. Keen. 2000. "Redistribution", in: A.B. Atkinson and F. Bourguignon (eds.) Handbook of Income Distribution, New York: ElsevierNorth Holland Publishers, pp. 677-789.

Bourguignon, F., and L. Pereira da Silva and N. Stern. 2002. "Evaluating the Poverty Impact of Economic Policies: Some Analytical Challenges", Stern Washington DC: The World Bank (Mimeo), 2002.

Brady, D. 2004. "The welfare state and relative poverty in rich western democracies, 1967-1997", Luxembourg Income Study Working Paper Series 390, Luxembourg.

Brandolini, A. 2006. "Measurement of income distribution in supranational entities: The case of the European Unio", Luxembourg Income Study Working Paper Series 452, Luxembourg.

Caminada, K. and Goudswaard, K.P. 2001. "International Trends in Income Inequality and Social Policy", International Tax and Public Finance 8 (4), pp. $395-415$.

Caminada, K. and Goudswaard, K.P. 2005. "Are Public and Private Social Expenditures Complementary?", International Advances in Economic Research 11 (2), pp. 175-189.

Cantillon, B., I. Marx and K. Van den Bosch. 2002. "The puzzle of egalitarianism: About the relationships between employment, wage inequality, social expenditures and poverty", Luxembourg Income Study Working Paper Series 337, Luxembourg.

European Commission. 2007. Joint Report on Social protection and social inclusion 2007. Social inclusion, pensions, healthcare and long term care, Luxembourg: Office for Official Publications of the European Communities.

European Commission. 2008. Joint Report on Social protection and social inclusion 2008. Social inclusion, pensions, healthcare and long term care, Luxembourg: Office for Official Publications of the European Communities. 
Caminada and Goudswaard: Effectiveness of Poverty Reduction in the EU

Eurostat. 2005. "The continuity of indicators during the transition between ECHP and EU-SILC", Working Paper and Studies, Eurostat.

Eurostat. 2007. Structural Indicators EU - Social Cohesion, http://epp.eurostat.ec.europa.eu/

Förster, M. 1993. "Comparing Poverty in 13 OECD Countries: Traditional and Synthetic Approaches", Luxembourg Income Study Working Paper 100, Luxembourg.

Förster, M., and M. Pearson. 2002. "Income distribution and poverty in the OECD area: trends and driving forces", OECD Economic Studies no. 34, 2002/1, Paris: OECD, pp. 7-39.

Förster, M., and M.M. d'Ercole. 2005. "Income Distribution and Poverty in OECD Countries in the Second Half of the 1990s", OECD Social, Employment and Migration Working Papers no. 22.

Gottschalk, P., and T.M. Smeeding. 1997. "Cross-National Comparisons of Earnings and Income Inequality”, Journal of Economic Literature 35 (June), pp. 633-687.

Gottschalk, P. and T.M. Smeeding. 2000. "Empirical Evidence on Income Inequality in Industrialized Countries", in: A.B. Atkinson and Bourgignon, F. (eds), Handbook of Income Distribution, New York: Elsevier-North Holland Publishers, pp. 261-308.

Guio, A.-C. 2005. "Income poverty and social exclusion in the EU25", Statistics in focus: population and social conditions, 13/2005, pp. 1-7.

Hagenaars, A., and K. de Vos. 1987. "The definition and measurement of poverty", The Journal of Human Resources 23 (2), pp. 211-221.

Haveman, R. 2008. "What Does It Mean to Be Poor in a Rich Society?", Institute for Research on Poverty Discussion Paper 1356-08, Madison.

Jesuit, D., and V. Mahler. 2004. "State redistribution in comparative perspective: A cross-national analysis of the developed countries", Luxembourg Income Study Working Paper Series 392, Luxembourg.

Kakwani, N., and J. Silber (eds.). 2007. The Many Dimensions of Poverty, New York: Palgrave Macmillan.

Kakwani, N., and J. Silber (eds.). 2008. Quantitative Approaches to Multidimensional Poverty Measurement, New York: Palgrave Macmillan. 
Kangas, O. and J. Palme. 2000. "Does Social Policy Matter? Poverty Cycles in OECD Countries", International Journal of Health Services 30 (2), pp. 335352 .

Kenworthy, L. 1999. "Do Social Welfare Policies Reduce Poverty? A CrossNational Assessment", Social Forces 77 (3), pp. 1119-1139.

Kim, H. 2000a. "Anti-Poverty Effectiveness of Taxes and Income Transfers in Welfare States”, International Social Security Review 53 (4), pp. 105-129.

Kim, H. 2000b. "Do welfare states reduce poverty? A critical shortcoming in the standard analysis of the anti-poverty effect of welfare states", Luxembourg Income Study Working Paper Series 233, Luxembourg.

Kühner, S. 2007. "Country-Level Comparisons of Welfare State Change Measures: Another Facet of the Dependent Variable Problem within the Comparative Analysis of the Welfare State?", Journal of European Social Policy 17 (1), pp. 5-18.

Leibfried, S. 2002. "Some Background Comments on the Extension of the Open Method of Co-ordination", Belgisch Tijdschrift voor Sociale Zekerheid 44 (3), pp. 473-479.

Mahler, V.A., and D.K. Jesuit. 2006. "Fiscal Redistribution in the Developed Countries: New Insights from the Luxembourg Income Study", SocioEconomic Review 4, pp. 483-511 (also published as Luxembourg Income Study Working Paper Series 392, Luxembourg).

Marcus, J., and S. Danziger. 2000. "Income Poverty in Advanced Countries", in: A.B. Atkinson, and Bourguignon, F. (eds.), Handbook of Income Distribution, New York: Elsevier-North Holland Publishers, pp. 309-378.

Musgrave, R.A., K.E. Case and H.B. Leonard. 1974. "The Distribution of Fiscal Burdens and Benefits", Public Finance Quarterly 2 (July), pp. 259-311.

Nell, G. 2005. "Prosperity and the welfare state: The effect of benefit generosity and wage coordination on absolute poverty and prosperity in cross-national perspective", Luxembourg Income Study Working Paper Series 424, Luxembourg.

Notten, G., and C. de Neuborg. 2007. "Relative or absolute poverty in the US and EU? The battle of the rates", MPRA Working Paper 5313, Munich.

OECD. 2007. Social Expenditure Database 1980-2003 (www.oecd.org/els/social/expenditure); download January $4^{\text {th }}, 2008$.

OECD. 2008. Growing unequal? Income distribution and Poverty in OECD Countries, Paris: OECD. 
Pestieau, P. 2006. The Welfare State in the European Union: Economic and Social Perspectives, Oxford: Oxford University Press.

Sainsbury, D., and A. Morissens. 2002. "European anti-poverty policies in the 1990s: Toward a common safety net", Luxembourg Income Study Working Paper Series 307, Luxembourg.

Scruggs, L., and J.P. Allan. 2006. "The Material Consequences of Welfare States: Benefit Generosity and Absolute Poverty in 16 OECD Countries", Comparative Political Studies 39, pp. 880-904 (also published as Luxembourg Income Study Working Paper Series 409, Luxembourg).

Smeeding, T. 2005. "Poor people in rich nations: The United States in comparative perspective", Luxembourg Income Study Working Paper Series 419, Luxembourg.

Smeeding, T., L. Rainwater, and G. Burtless. 2000. "United States Poverty in a Cross-National Context", Luxembourg Income Study Working Paper Series 244, Luxembourg.

Smolensky, E., W. Hoyt and S. Danziger. 1987. "A Critical Survey of Efforts to Measure Budget Incidence", in: H.M. van de Kar; B.L. Wolfe (eds.), The Relevance of Public Finance for Policy-Making, Proceedings IIFP Congress 1985, Detroit, pp. 165-179.

Wu, K. 2005. "How Social Security Keeps Older Persons Out of Poverty across Developed Countries", Luxembourg Income Study Working Paper 410, Luxembourg. 